\title{
SHRIMP U-Pb EVIDENCE FOR A LATE SILURIAN AGE OF METASEDIMENTARY ROCKS IN THE MERRIMACK AND PUTNAM-NASHOBA TERRANES, EASTERN NEW ENGLAND
}

\author{
R. P. WINTSCH*, J. N. ALEINIKOFF**, G. J. WALSH***, W. A. BOTHNER****, \\ A. M. HUSSEY, $\mathrm{II}^{\ddagger}$, and C. M. FANNING ${ }^{\S}$
} ABSTRACT. U-Pb ages of detrital, metamorphic, and magmatic zircon and metamor-
phic monazite and titanite provide evidence for the ages of deposition and metamor-
phism of metasedimentary rocks from the Merrimack and Putnam-Nashoba terranes
of eastern New England. Rocks from these terranes are interpreted here as having
been deposited in the middle Paleozoic above Neoproterozoic basement of the
Gander terrane and juxtaposed by Late Paleozoic thrusting in thin, fault-bounded
slices.

The correlative Hebron and Berwick formations (Merrimack terrane) and Tatnic Hill Formation (Putnam-Nashoba terrane), contain detrital zircons with Mesoproterozoic, Ordovician, and Silurian age populations. On the basis of the age of the youngest detrital zircon population $(\sim 425 \mathrm{Ma})$, the Hebron, Berwick and Tatnic Hill formations are no older than Late Silurian (Wenlockian). The minimum deposition ages of the Hebron and Berwick are constrained by ages of cross-cutting plutons $(414 \pm 3$ and $418 \pm 2 \mathrm{Ma}$, respectively). The Tatnic Hill Formation must be older than the oldest metamorphic monazite and zircon $(\sim 407 \mathrm{Ma})$. Thus, all three of these units were deposited between $\sim 425$ and $418 \mathrm{Ma}$, probably in the Ludlovian. Age populations of detrital zircons suggest Laurentian and Ordovician arc provenance to the west. High grade metamorphism of the Tatnic Hill Formation soon after deposition probably requires that sedimentation and burial occurred in a fore-arc environment, whereas time-equivalent calcareous sediments of the Hebron and Berwick formations probably originated in a back-arc setting.

In contrast to age data from the Berwick Formation, the Kittery Formation contains primarily Mesoproterozoic detrital zircons; only 2 younger grains were identified. The absence of a significant Ordovician population, in addition to paleocurrent directions from the east and structural data indicating thrusting, suggest that the Kittery was derived from peri-Gondwanan sources and deposited in the Fredericton Sea. Thus, the Kittery should not be considered part of the Laurentian-derived Merrimack terrane; it more likely correlates with the early Silurian Fredericton terrane of northeastern New England and Maritime Canada.

\section{INTRODUCTION}

The evolution of an orogenic belt cannot be understood without knowledge of both the age and the distribution of its component parts, and the history of assembly of these parts. Progress in understanding the Paleozoic tectonic evolution of eastern New England has been stymied by the lack of firm evidence of the ages of deposition and metamorphism of rocks in its major metasedimentary belts. Fossil control of depositional ages is lacking due to deformation and metamorphism, and geochronology has not produced enough reliable prograde metamorphic ages of these rocks to constrain their time(s) of metamorphism.

Two persistently enigmatic belts in the eastern New England Appalachians are the Merrimack and Putnam-Nashoba terranes. These belts are located between the Cen-

\footnotetext{
* Department of Geological Sciences, Indiana University, Bloomington, Indiana 47405; wintsch@indiana.edu

** U.S. Geological Survey, Mail Stop 964, Denver Federal Center, Denver, Colorado 80225

*** U.S. Geological Survey, P.O. Box 628, Montpelier, Vermont 05602

**** Earth Sciences, University of New Hampshire, Durham, New Hampshire 03824

$\ddagger$ Bowdoin College, 6800 College Station, Brunswick, Maine 04011-8468

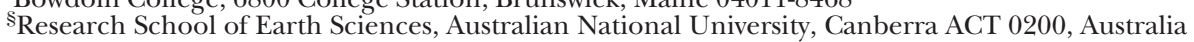


tral Maine terrane to the west, and the Avalon terrane to the east (fig. 1), and are interpreted on a regional scale to be members of the peri-Gondwanan belts of Hibbard and others (2006). However, the relationships of Merrimack and Putnam-Nashoba terranes to the Avalon and the Central Maine terranes, and even to each other, have been and remain contested. Outstanding questions involve the depositional ages of the protoliths of metasedimentary units, and the tectonic significance of the belts, as either lithotectonic terranes, as (meta)sedimentary troughs, or as groups of formations. For example, both the Putnam-Nashoba and Merrimack terranes have been interpreted to be Late Proterozoic, Ordovician, or Silurian, based on variably tenuous stratigraphic correlations, contact relationships with adjacent rocks, and apparent ages of intrusive rocks (Rodgers, 1981; Zen and others, 1983; Bothner and others, 1984; Rodgers, 1985; Barosh and Moore, 1988; Pease, 1989; Robinson and Goldsmith, 1991; Bothner and others, 1994; Robinson and others, 1998; Hussey and others, 1999). Stratigraphic assignment is further complicated by significant strike-parallel faulting that juxtaposes rocks of the Central Maine, Merrimack, Putnam-Nashoba, and Avalon terranes with alternating grades of metamorphism. Tremblay and Pinet (2005) include Merrimack terrane rocks with rocks of the Central Maine terrane and believe that they correlate in age and tectonic environment with the Connecticut Valley - Gaspé terrane (fig. 1), having formed synchronously but in two separate depositional basins. However, without more information on provenance, the times of deposition, and the times of metamorphism of these rocks, a refined understanding of the early Paleozoic evolution of the New England Appalachians is not possible.

This study has been undertaken to establish the age and provenance of the rocks of the Merrimack and Putnam-Nashoba terranes. We approach the problem by dating detrital zircons, and metamorphic monazite, titanite, and zircon rims in metasedimentary rocks, and magmatic zircon from cross-cutting plutonic rocks. These results are then applied to stratigraphic and tectonic issues.

\section{GEOLOGIC SETTING}

The tectonic settings of the Avalon and Central Maine terranes are well established, but the roles of the Merrimack and Putnam-Nashoba terranes sandwiched between them (fig. 1) remain much debated. Each terrane is a sliver of rock separated from adjacent blocks by ductile to brittle faults that obliquely cut stratigraphic units, and commonly juxtapose rocks with differing times and grades of metamorphism (Wintsch and others, 1993). Final assembly of these terranes probably was not completed until the Permian. The Avalon terrane is composed primarily of Neoproterozoic intrusive and extrusive rocks, unconformably overlain by Paleozoic sediments, and intruded by Paleozoic igneous rocks (see for example, Skehan and Rast, 1990; Zartman and Marvin, 1991). At the latitude of our study, the Central Maine terrane contains primarily Silurian and Devonian metasedimentary rocks that have been metamorphosed to moderate and high grades, and intruded by a suite of mid-Paleozoic intrusive rocks (see for example, Zartman and Naylor, 1984; Bradley and others, 2000; Moench and Aleinikoff, 2003).

\section{Merrimack Terrane}

The Merrimack terrane is a fault-bounded slice of rocks extending from southcentral Connecticut to the Gulf of Maine (fig. 1), with protoliths of variably calcareous, sandy, silty, and muddy sediments, and intruded mafic and felsic plutonic rocks. Toward the northwest the Merrimack terrane is structurally overlain by amphibolite facies rocks of the Central Maine terrane and orthogneisses of the Massabesic gneiss complex. Toward the southeast, it is in fault contact with, and probably overlies amphibolite facies rocks of the Putnam-Nashoba terrane in Connecticut (fig. 2) and Massachusetts (fig. 1), and with the Rye complex in New Hampshire (fig. 3). Within 


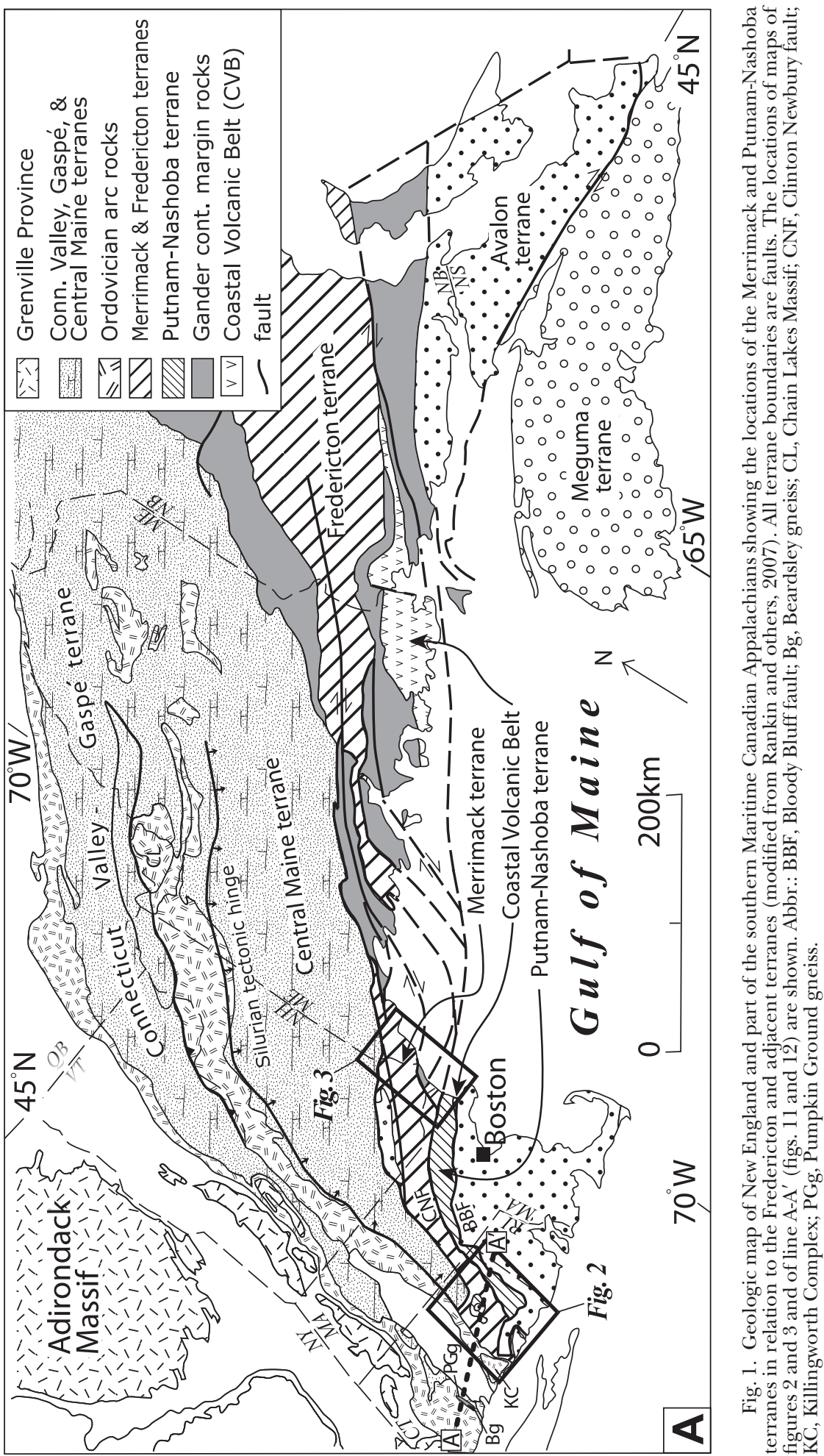




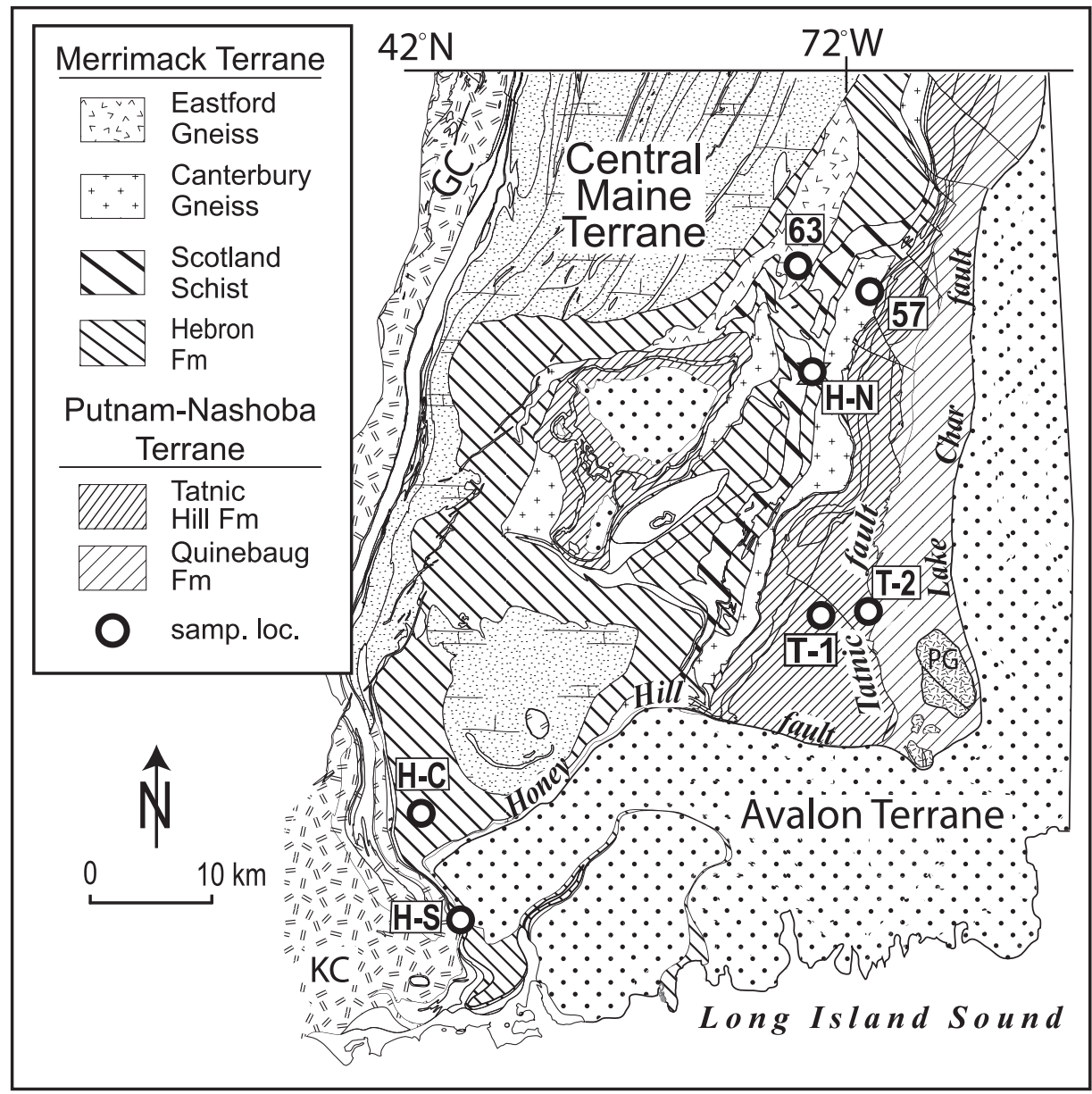

Fig. 2. Geologic map of most of eastern Connecticut (adapted from Rodgers, 1985) showing the Merrimack (NW rule and medium gray) and Putnam-Nashoba terrane rocks (NE rule and dark gray) relative to surrounding rocks of the Avalon (large dots) and Central Maine (calcareous sand) terranes, and other Ordovician intrusive $($ random $=$ ) and Devonian $(+,>$ patterns) rocks. Locations of samples analyzed in this study shown with an open circle. Abbr.: GC, Glastonbury gneiss complex; KC, Killingworth Complex; PG, Preston gabbro.

the Merrimack terrane in Connecticut, garnet-grade metamorphism increases to sillimanite grade to the west and south (Snyder, 1964). In New Hampshire and Massachusetts, the grade of metamorphism increases from greenschist facies in the east to amphibolite facies in the west (Zen and others, 1983; Lyons and others, 1997).

Map units of the Merrimack terrane in Connecticut include the Hebron Formation, Scotland Schist, and smaller unnamed units (for example, Snyder, 1964); these are shown in figure 2 following Rodgers (1985). Subsequent proposals by Pease (1989) to subdivide the Hebron Formation, and by Wintsch and others (1993) to include map units from the structurally lower Tatnic Hill Formation in the Merrimack terrane are not adopted here.

In New Hampshire and southern Maine, three major units are mapped in the Merrimack terrane: the Berwick, Eliot, and Kittery formations. These, together with 


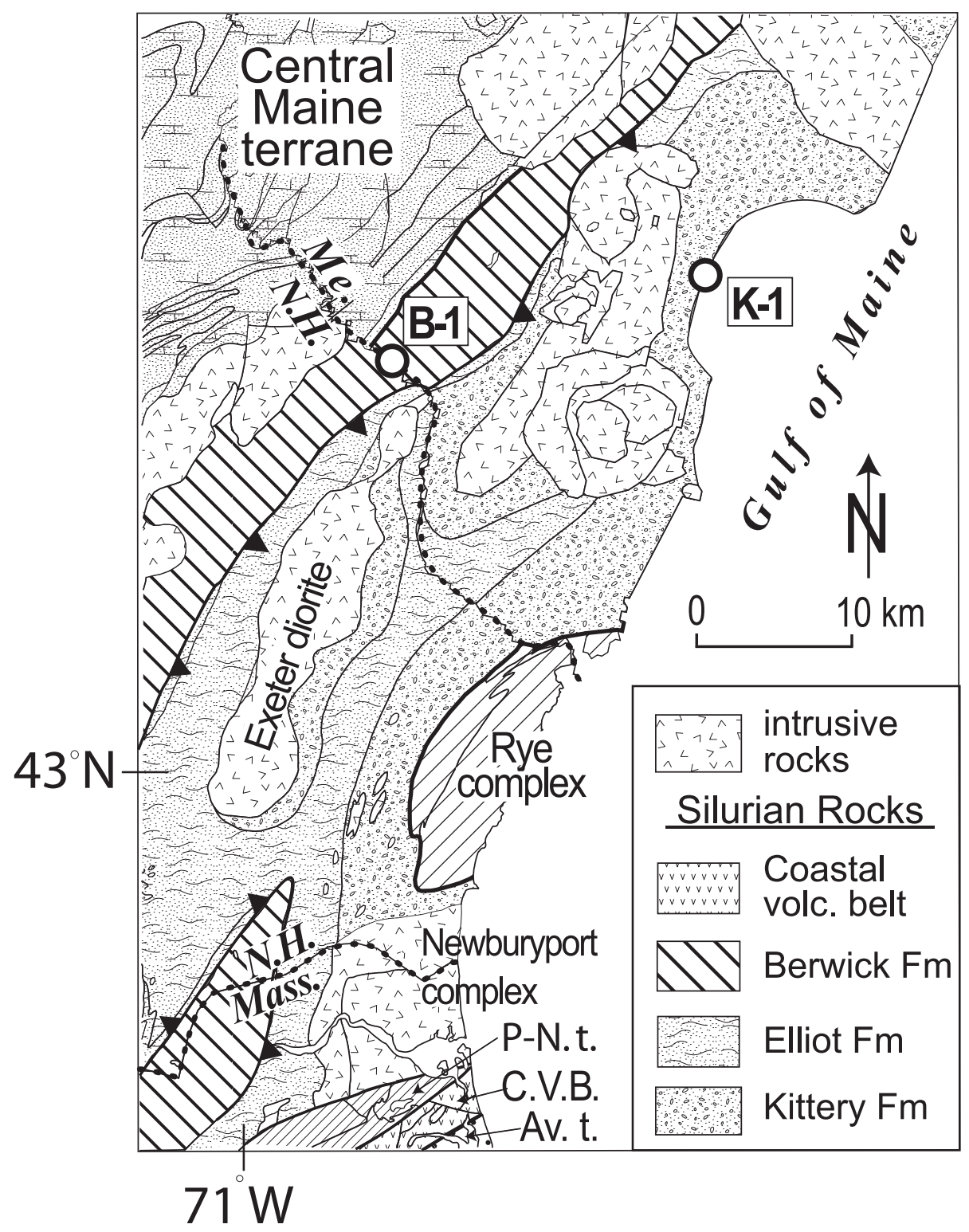

Fig. 3. Geologic map of coastal New Hampshire and southern Maine showing Silurian metasedimentary rocks in fault contact with the Rye complex and the Central Maine terrane. The Early Silurian Eliot and Kittery formations are faulted over the Late Silurian Berwick Formation, and all are intruded by the latest Silurian Newburyport complex and the early Devonian Exeter Diorite. Locations of samples described in the text are indicated by the open circles. Adapted from Lyons and others (1997) and Bothner and others (2004).

several thinner pelitic units, make up the 'Merrimack Group' of Lyons and others (1989; fig. 3). The Berwick and Eliot are composed of alternating 1 to $5 \mathrm{~cm}$ thick layers of variably calcareous sandy and less calcareous muddy protoliths. The Kittery Formation contains largely calcareous metasiltstones and metasandstones, with a few coarser grained beds. The stratigraphic order of these units has been contested in the 
literature, but it is now accepted that in New Hampshire and southwestern Maine the Eliot and overlying Kittery formations structurally overlie the Berwick (Lyons and others, 1997). Furthermore, we now believe that the faults that everywhere separate the Eliot and Kittery formations from the Berwick Formation are thrusts that placed the latter two older formations upon the younger Berwick prior to the intrusion of several plutons (fig. 3; see Tectonic Speculations; Bothner and others, 2004.).

\section{Putnam-Nashoba Terrane}

The Putnam-Nashoba terrane (fig. 1) contains a mixed assemblage of medium to high grade paragneisses and orthogneisses (Hepburn and others, 1995). To the west and northwest it is separated from the structurally overlying Merrimack terrane by the Clinton-Newbury fault system (CNF, fig. 1; Goldsmith, 1991a) and its southern extension (Wintsch and others, 1992). To the east and southeast it is separated from the underlying Avalon terrane by the Honey Hill-Lake Char-Bloody Bluff fault system (BBF, fig. 1; fig. 2) which has a complicated history of reactivation (Goldstein, 1989; Goldsmith, 1991a; Wintsch and others, 1992).

In Connecticut, intermediate to mafic metaigneous rocks of the Quinebaug Formation are structurally overlain by pelitic schists of the Tatnic Hill Formation (Dixon, 1964; Rodgers, 1985; fig. 2). The Tatnic (thrust) fault separates these two units (fig. 2) and obscures any stratigraphic relationships between them. In Massachusetts, this lithologic and structural package is roughly repeated, with mafic amphibole schists and gneisses of the Marlboro Formation overlain by pelitic schists of the Nashoba Formation (Goldsmith, 1991b). The age of these paragneisses must be older than early Paleozoic mafic and felsic intrusive rocks (Zartman and Naylor, 1984; Acaster and Bickford, 1999), and may be as old as Late Cambrian, based on a U-Pb igneous zircon date of $\sim 500 \mathrm{Ma}$ in associated metavolcanics (Hepburn and others, 1995). However, all metasedimentary and metavolcanic rocks and most intrusive rocks are metamorphosed to middle or upper amphibolite facies, making detailed stratigraphic correlations difficult.

\section{METHODS}

\section{Strategy}

Due to its refractory character, igneous zircon can remain intact through highgrade metamorphism and even anatexis. U-Pb geochronologic studies conducted over the past 50 years have documented inheritance of older zircon as inclusions within younger magmatic zircon. In fact, zircon commonly resists dissolution and reaction, developing only rims of newly crystallized material during metamorphism. The closure temperature of the U-Pb system in zircon is $>800^{\circ} \mathrm{C}$ (Cherniak and Watson, 2001), higher than the temperatures attained by most geologic processes, so that Pb-loss by diffusional processes is rarely documented, and overgrowths record the time of their own crystallization. To decipher the history of zircons composed of multiple age zones, it is necessary to use in situ microanalysis of small, homogeneous domains.

During high-grade metamorphism of the metasedimentary rocks of the Merrimack and Putnam-Nashoba terranes of Connecticut, many zircons developed overgrowths. These detrital zircon grains thus preserve evidence of both provenance (age range of cores) and subsequent metamorphisms (ages of overgrowths). The age of deposition is constrained to be younger than the youngest population of detrital zircon cores and older than the oldest group of metamorphic overgrowths. However, detrital grains can also contain metamorphic overgrowths formed prior to sedimentary deposition, so a possible (although rare) complicating factor is distinguishing between preand post-depositional metamorphic rims.

To understand age distributions, the origin of dated zones must be correctly interpreted. Magmatic zircon usually displays concentric oscillatory zoning in cathodolu- 
minescence (CL) imaging, whereas metamorphic zircon is commonly either unzoned or shows broad irregular patchwork zoning in CL (see for example, Corfu and others, 2003). Another distinguishing characteristic is that magmatic zircon usually has $\mathrm{Th} / \mathrm{U}$ of about 0.3 to 0.8 , whereas metamorphic zircon typically has very low $\mathrm{Th} / \mathrm{U}$ of $<0.1$ (Hoskin and Schaltegger, 2003; see Age of Deposition).

\section{Analytical Procedures}

Zircon and monazite were extracted from $\sim 5$ to $10 \mathrm{~kg}$ rock samples by routine mineral separation processes, including crushing, pulverizing, Wilfley table concentration of heavy minerals, and purification of mineral fractions using magnetic separation and methylene iodide. Detrital zircons were sprinkled onto double-stick tape to obtain relatively unbiased samples. Individual grains of monazite and titanite were handpicked under a binocular microscope. All samples were mounted in epoxy, ground to nearly half-thickness, and polished using $6 \mu \mathrm{m}$ and $1 \mu \mathrm{m}$ diamond suspension. All grains were digitally imaged in both transmitted and reflected light to identify areas free from inclusions, cracks, and other imperfections. Using the scanning electron microscope, zircons were imaged by cathodoluminescence (CL) to distinguish cores and overgrowths; monazites and titanites were imaged by back-scattered electrons (BSE).

U-Pb ages of zircon and monazite were determined using the USGS/Stanford sensitive high resolution ion microprobe-reverse geometry (SHRIMP-RG) at Stanford University, following the methods described in Williams (1998); titanite was analyzed on SHRIMP II at the Research School of Earth Sciences, Australian National University. The area excavated by the primary oxygen ion beam was about 25 to $30 \mu \mathrm{m}$ in diameter for zircon and titanite, and about 15 to $20 \mu \mathrm{m}$ for monazite. ${ }^{206} \mathrm{~Pb} /{ }^{238} \mathrm{U}$ ages were corrected for instrument fractionation using zircon standard R33 (419 $\pm 1 \mathrm{Ma}$; Black and others, 2004), monazite standard 44069 (424 $\pm 1 \mathrm{Ma}$; Aleinikoff and others, 2006) or titanite standard BLR-1 (1047 $\pm 1 \mathrm{Ma}$, Aleinikoff and others, 2007). Uranium concentrations are believed to be accurate to \pm 20 percent. Raw data were reduced using Squid 1 (Ludwig, 2001) and plotted using Isoplot 3 (Ludwig, 2003). For detrital zircons from metasedimentary rocks, U-Pb data are plotted on Tera-Wasserburg concordia diagrams to display degree of discordance. Analyses of detrital zircons that are less than 10 percent discordant (table 1) are used to construct relative probability age plots. Specifically, we use the ${ }^{206} \mathrm{~Pb} /{ }^{238} \mathrm{U}$ age for zircons younger than about 1200 $\mathrm{Ma}$, and ${ }^{207} \mathrm{~Pb} /{ }^{206} \mathrm{~Pb}$ ages older than about $1200 \mathrm{Ma}$. A well-known phenomenon first documented by Williams and Hergt (2000) is that SHRIMP analyses of zircons containing $>\sim 2500 \mathrm{ppm}$ uranium can result in ${ }^{206} \mathrm{~Pb} /{ }^{238} \mathrm{U}$ ages that are too old, presumably due to a change in instrument fractionation (that is, a calibration shift). Data from such high-U concentration, reversely discordant metamorphic zircons with ${ }^{206} \mathrm{~Pb} /{ }^{238} \mathrm{U}$ ages older than about $405 \mathrm{Ma}$ have been excluded from the relative probability plots below. U-Pb data from magmatic zircons and metamorphic monazite are plotted on Tera-Wasserburg concordia plots to visually determine coherent ages groups. Weighted averages of individual ${ }^{206} \mathrm{~Pb} /{ }^{238} \mathrm{U}$ ages are calculated to obtain an age for each sample. For titanite, lower intercept concordia ages are calculated through data that are uncorrected for common $\mathrm{Pb}$, using the Isoplot 3-D linear regression (Ludwig, 2003). In this study we follow the time scale of Gradstein and others (2004).

RESULTS

A total of about 400 zircon grains from nine samples were analyzed for this study: samples of five metasedimentary rocks and two igneous rocks from the Merrimack terrane, and two samples of metasedimentary rocks of the Tatnic Hill Formation from the Putnam-Nashoba terrane (tables 1 and 2). In addition, 37 grains of titanite from 


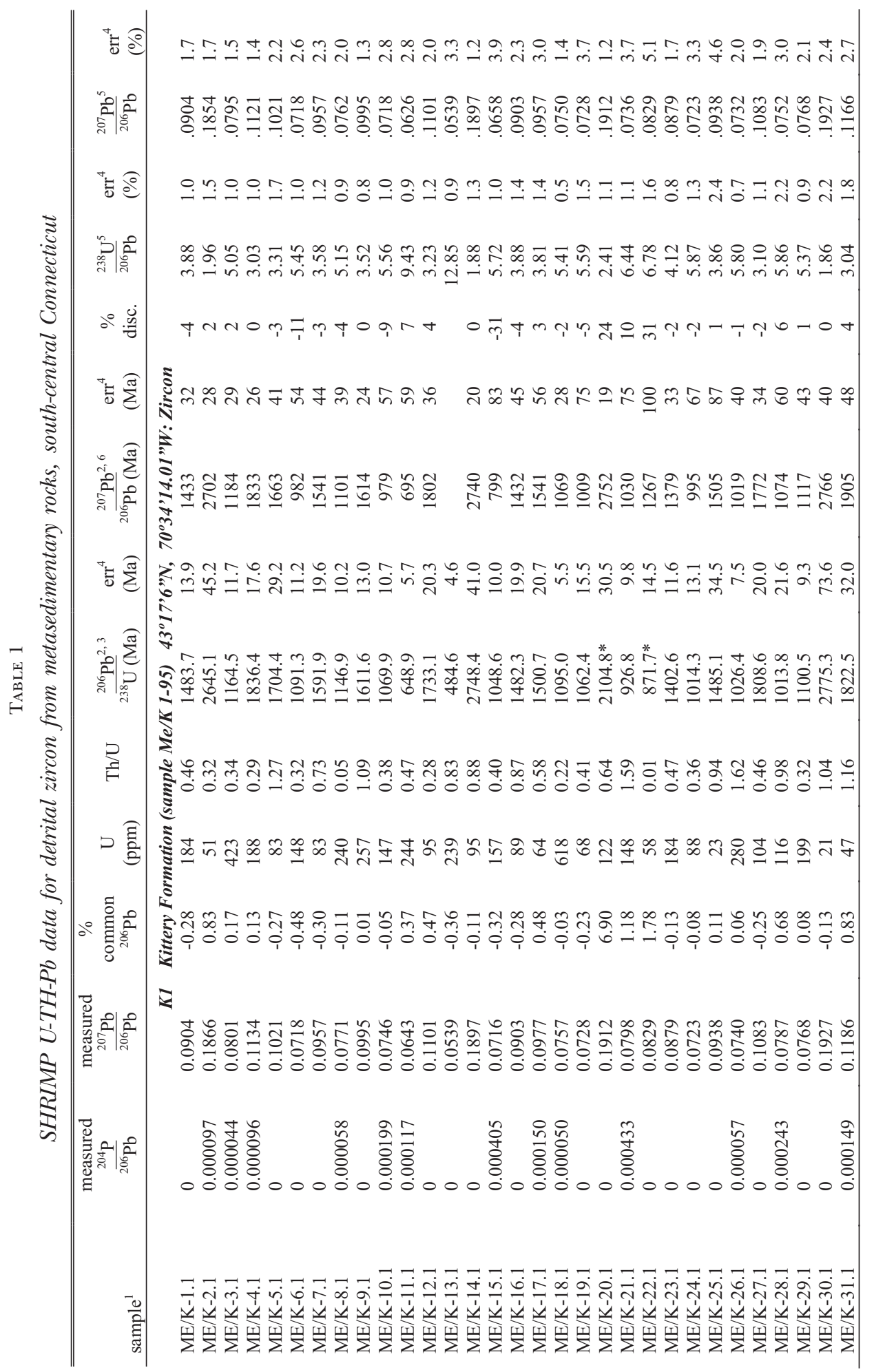


sedimentary rocks in the Merrimack and Putnam-Nashoba terranes, eastern New England 127

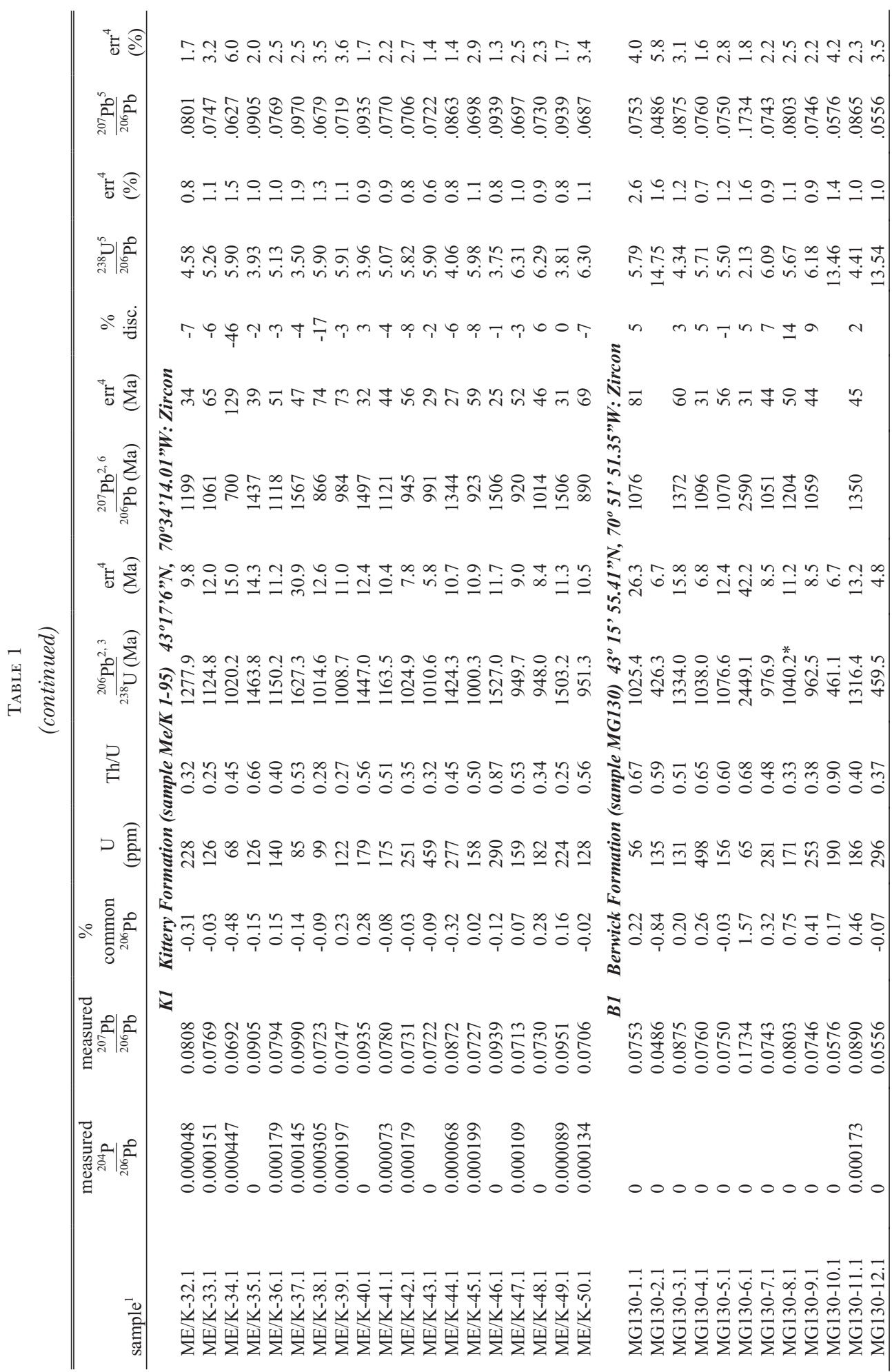




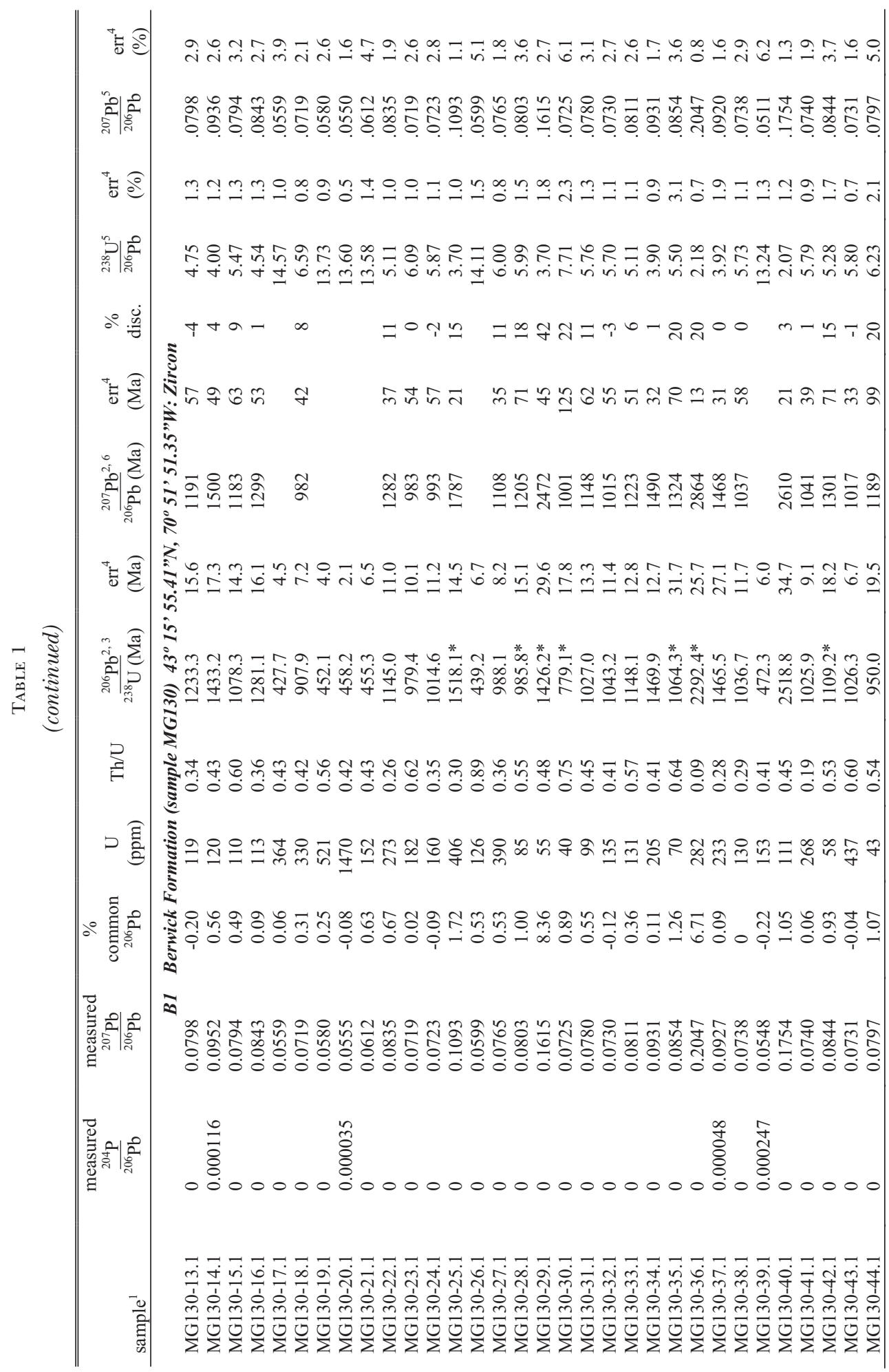


sedimentary rocks in the Merrimack and Putnam-Nashoba terranes, eastern New England 129

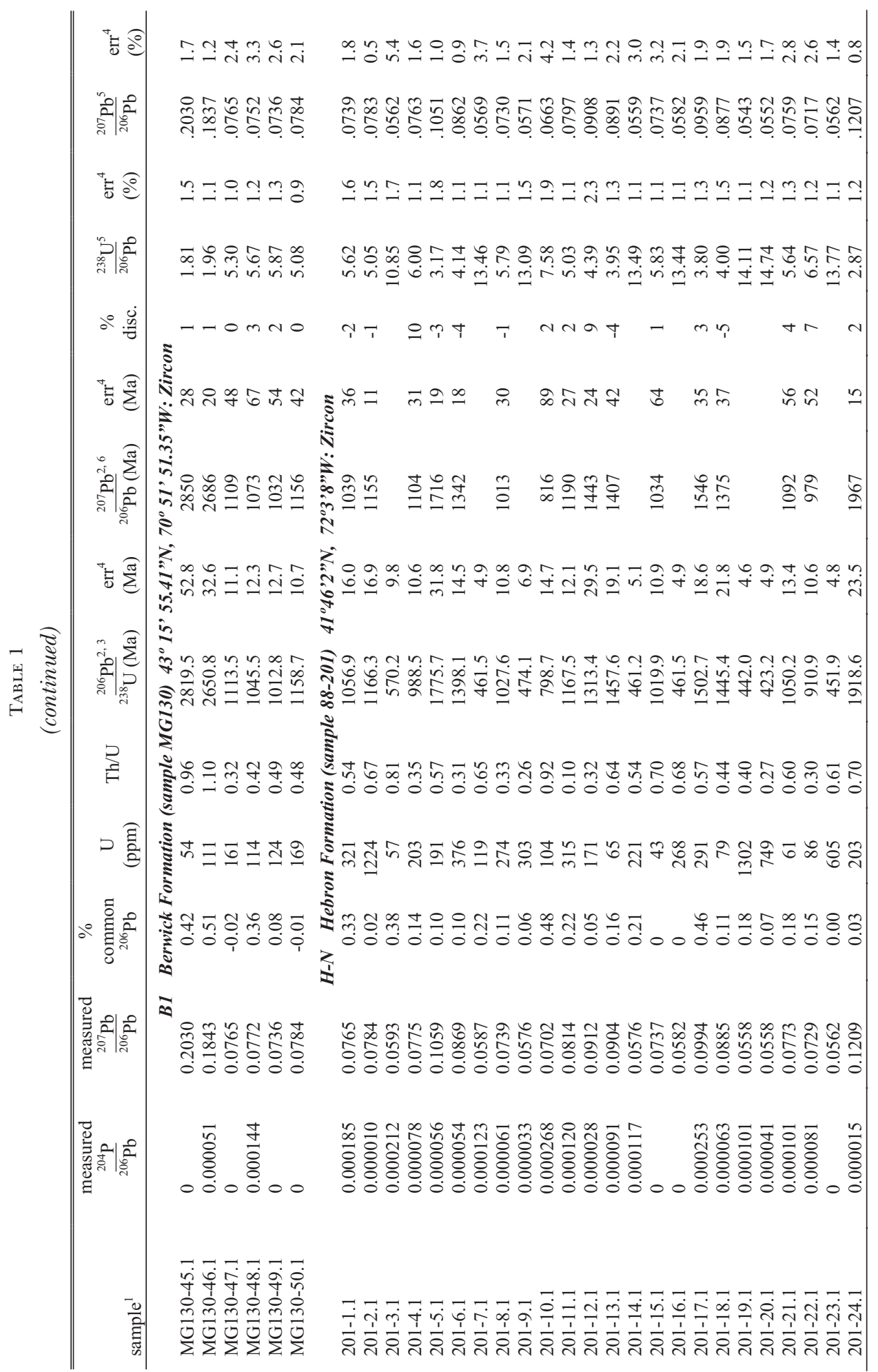




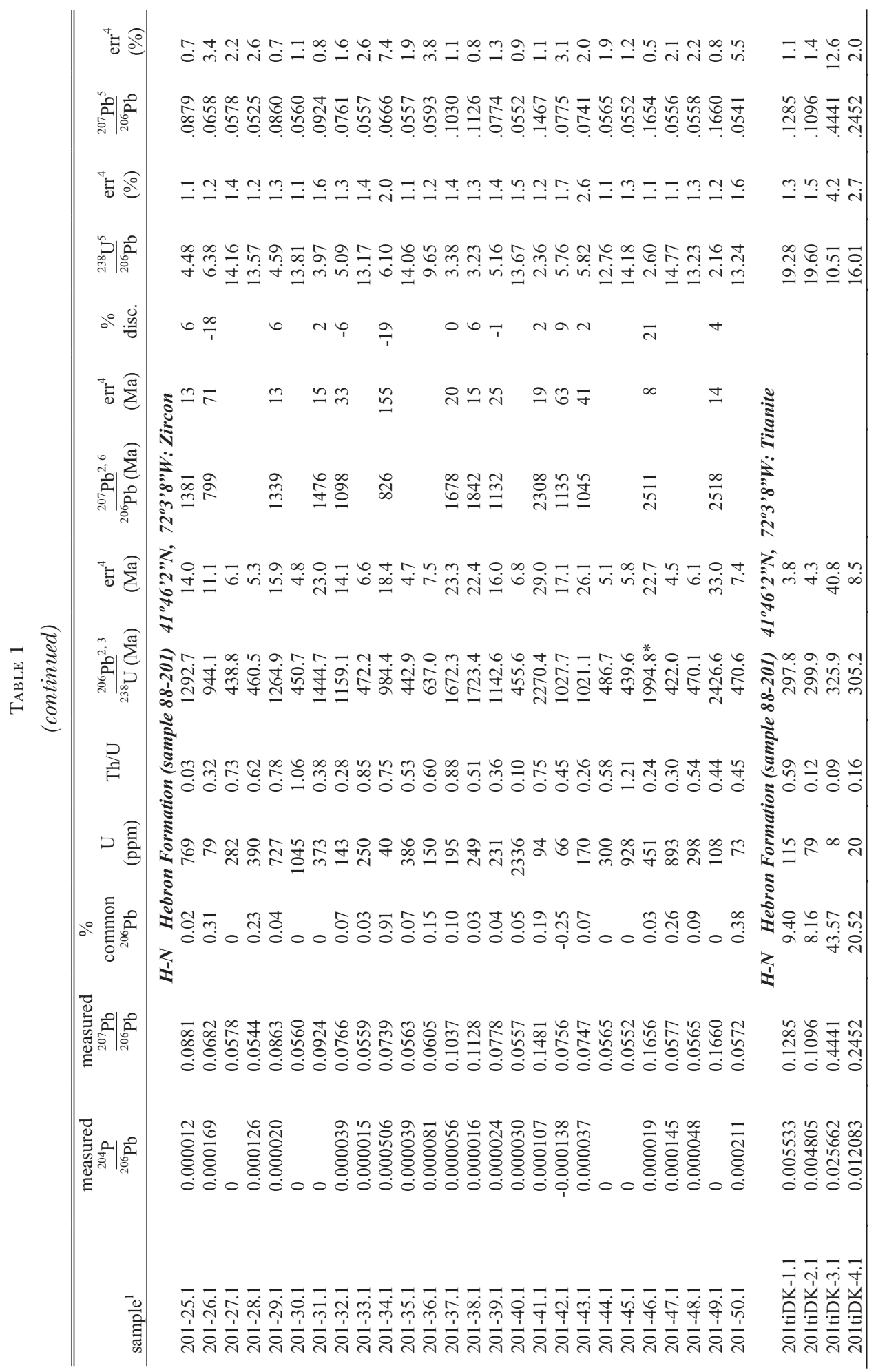


sedimentary rocks in the Merrimack and Putnam-Nashoba terranes, eastern New England 131

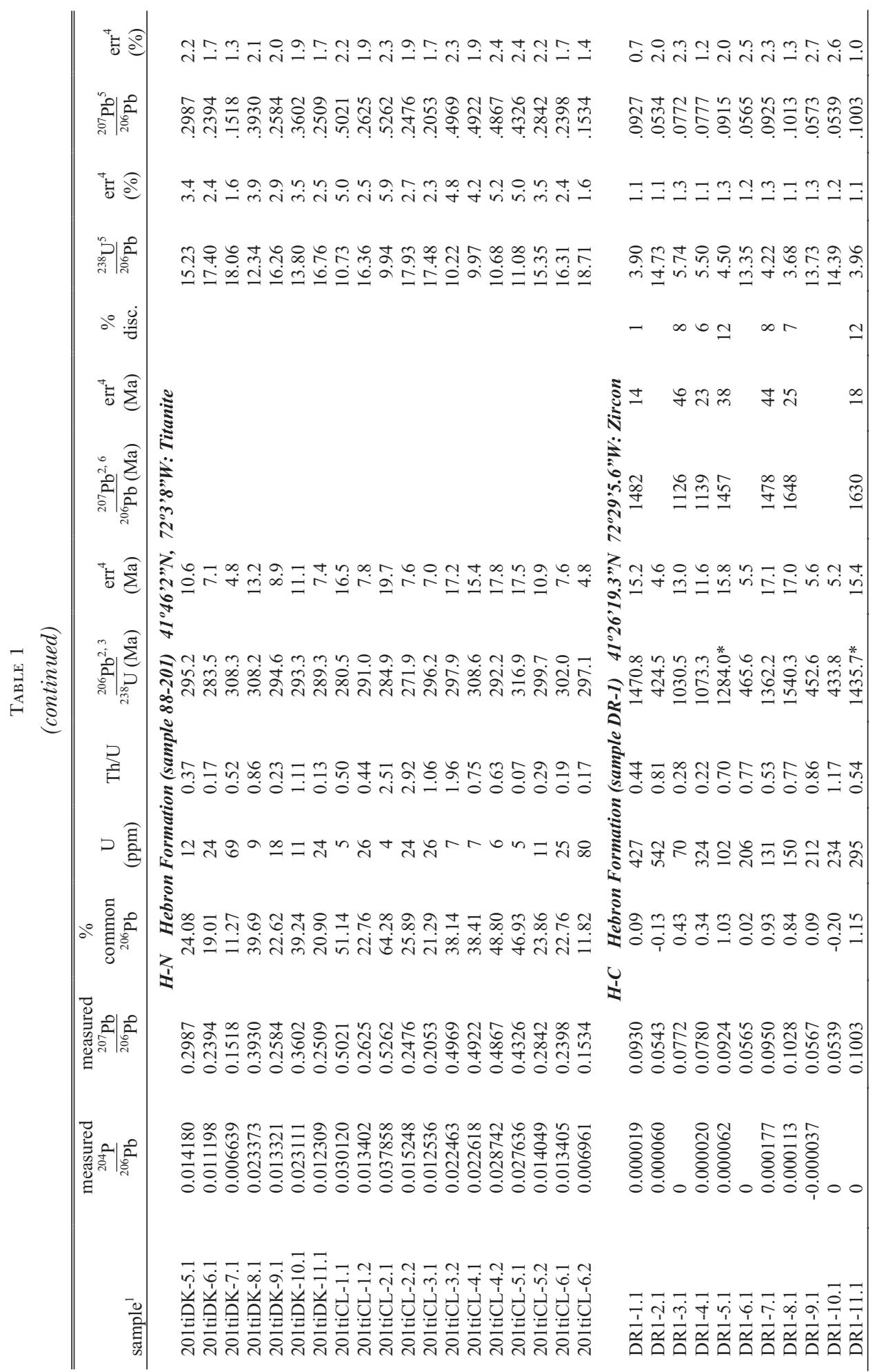




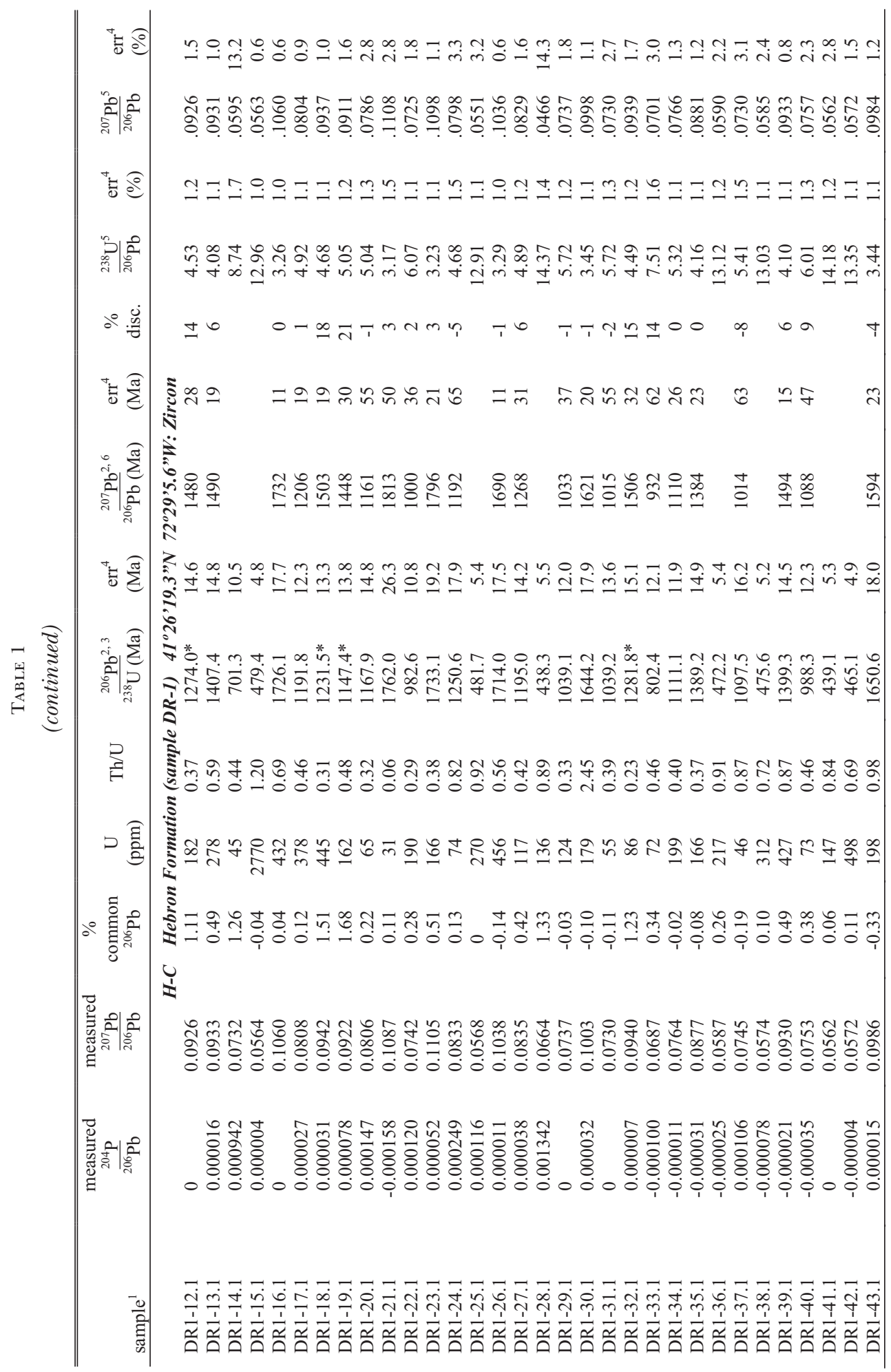


sedimentary rocks in the Merrimack and Putnam-Nashoba terranes, eastern New England 133

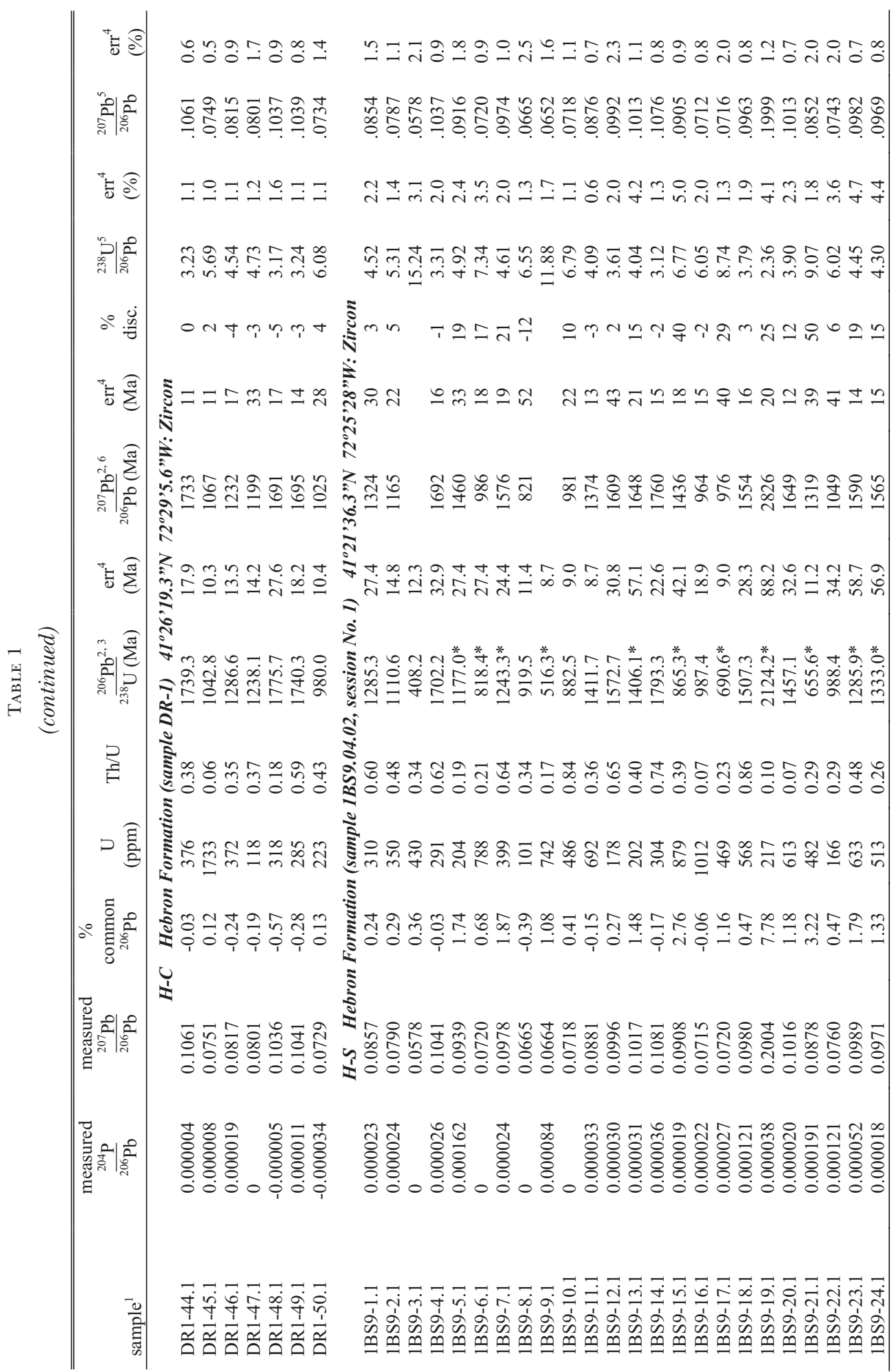




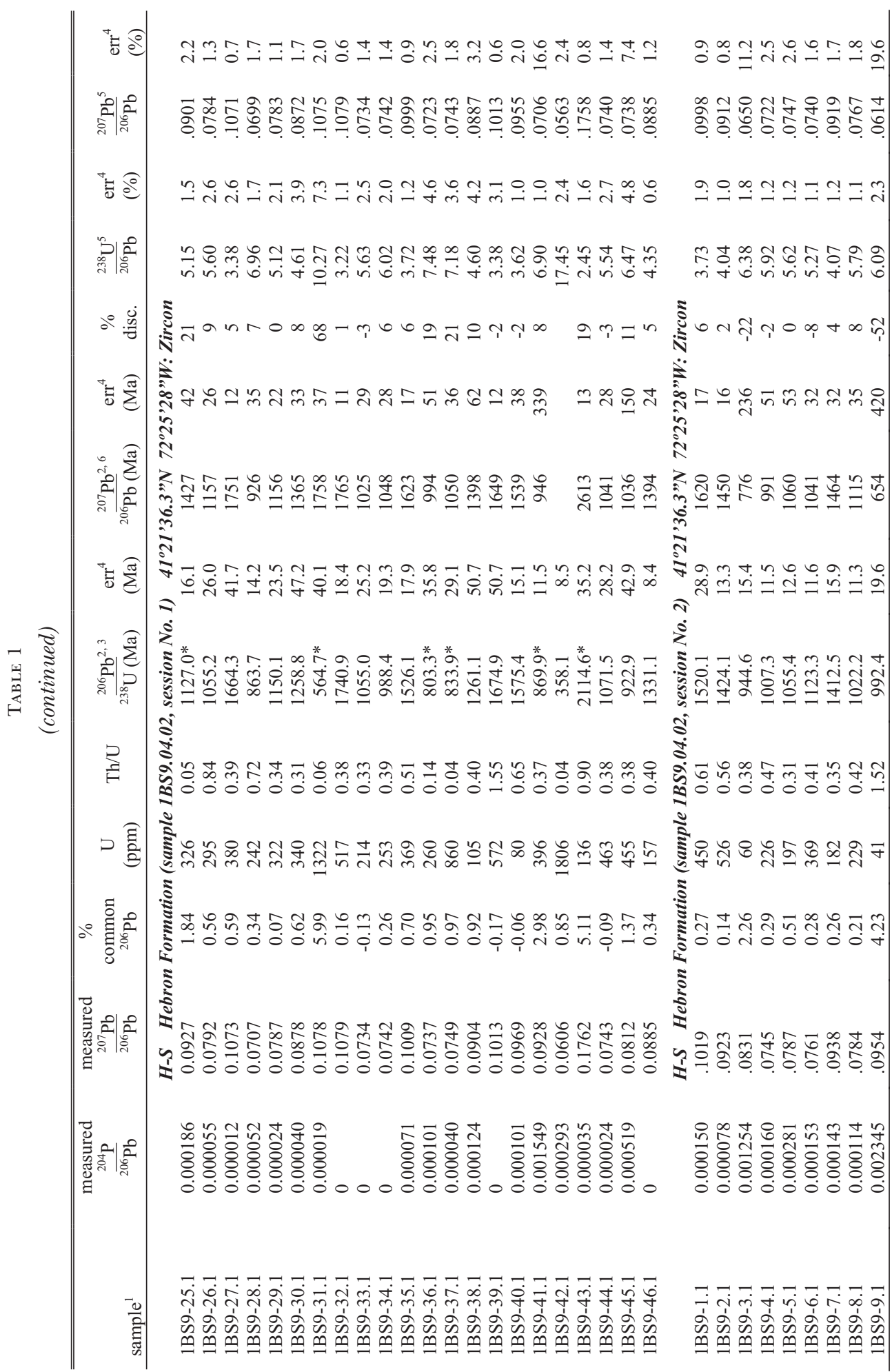


sedimentary rocks in the Merrimack and Putnam-Nashoba terranes, eastern New England 135

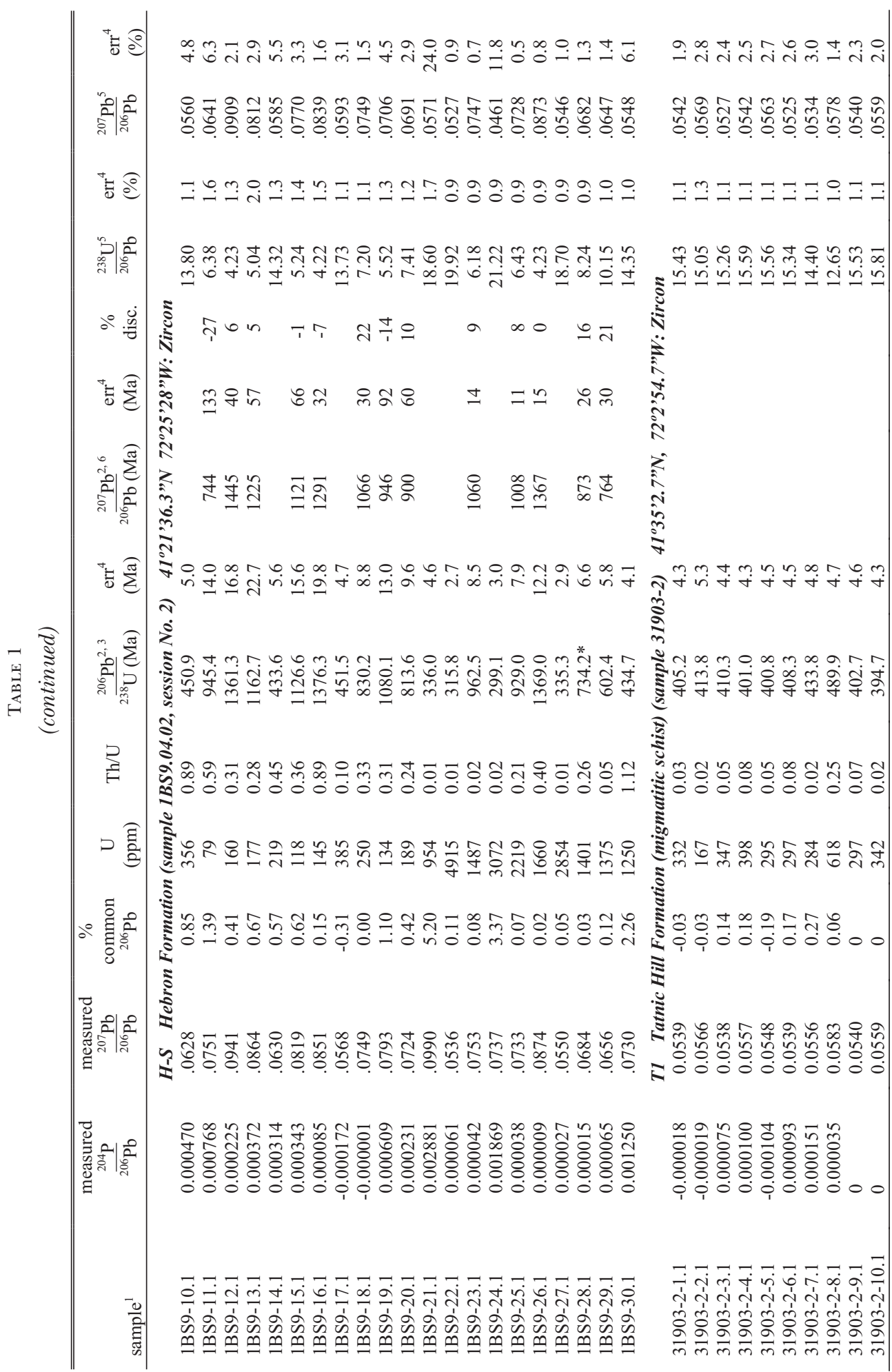




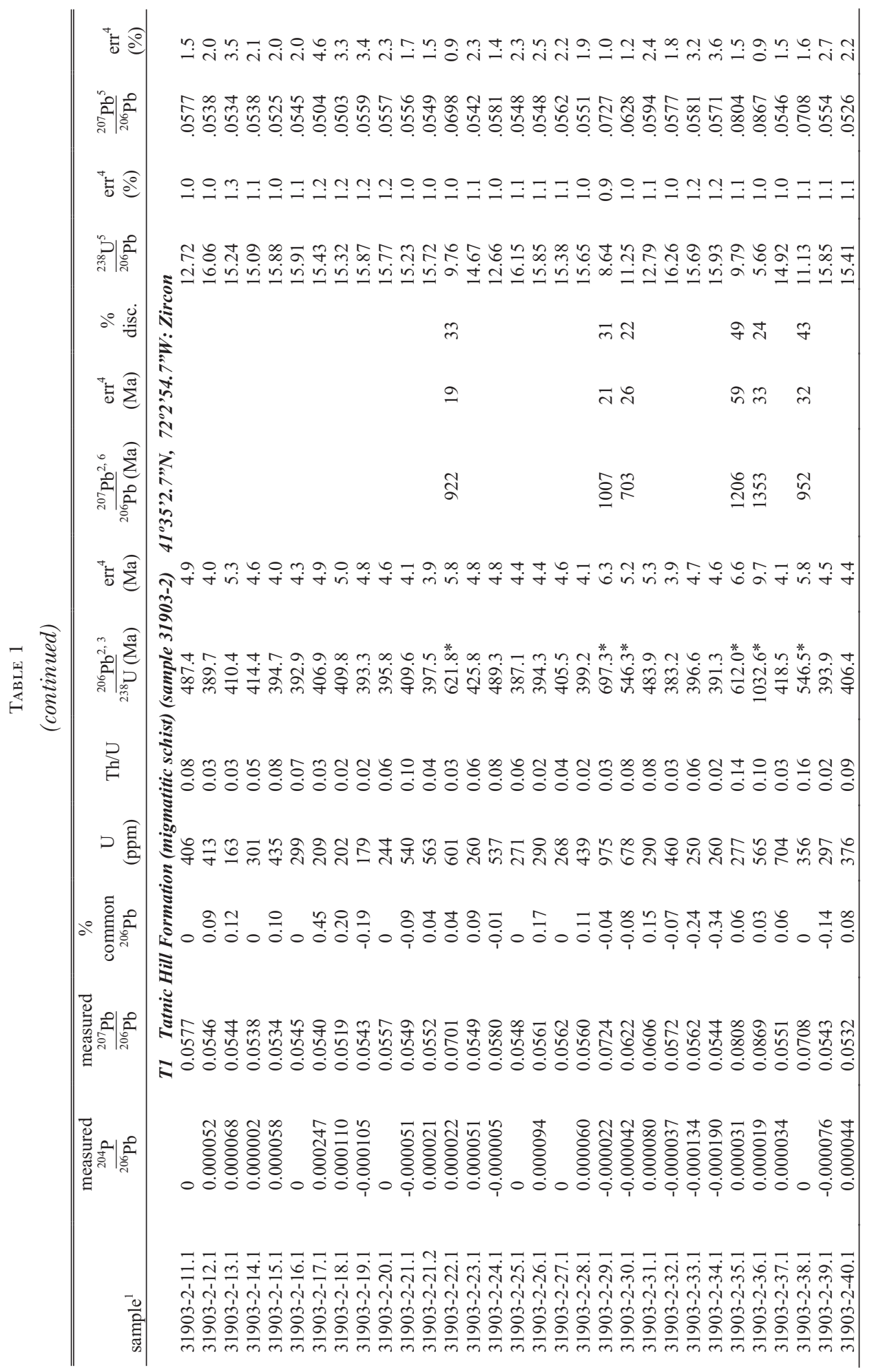


sedimentary rocks in the Merrimack and Putnam-Nashoba terranes, eastern New England 137

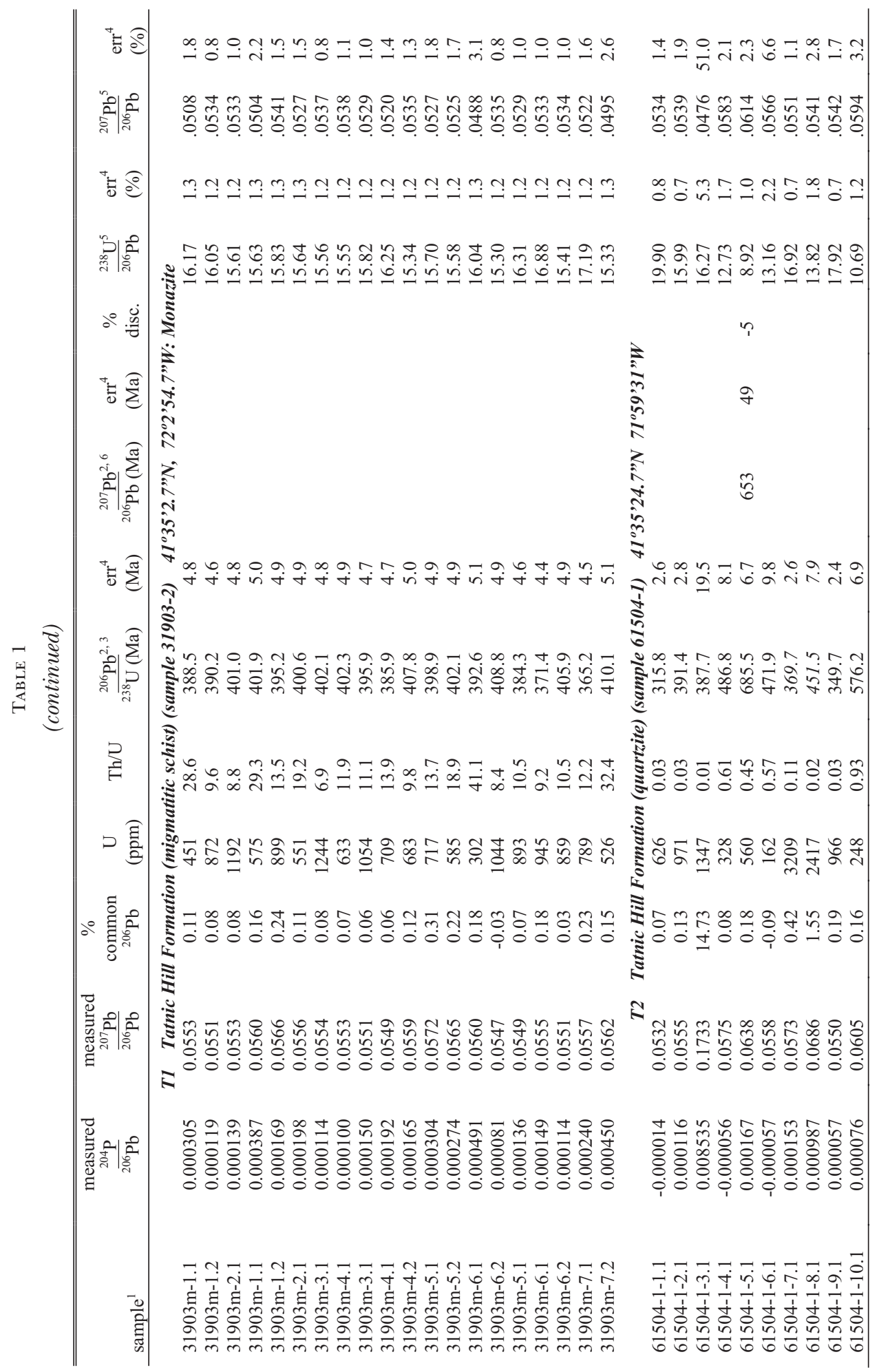




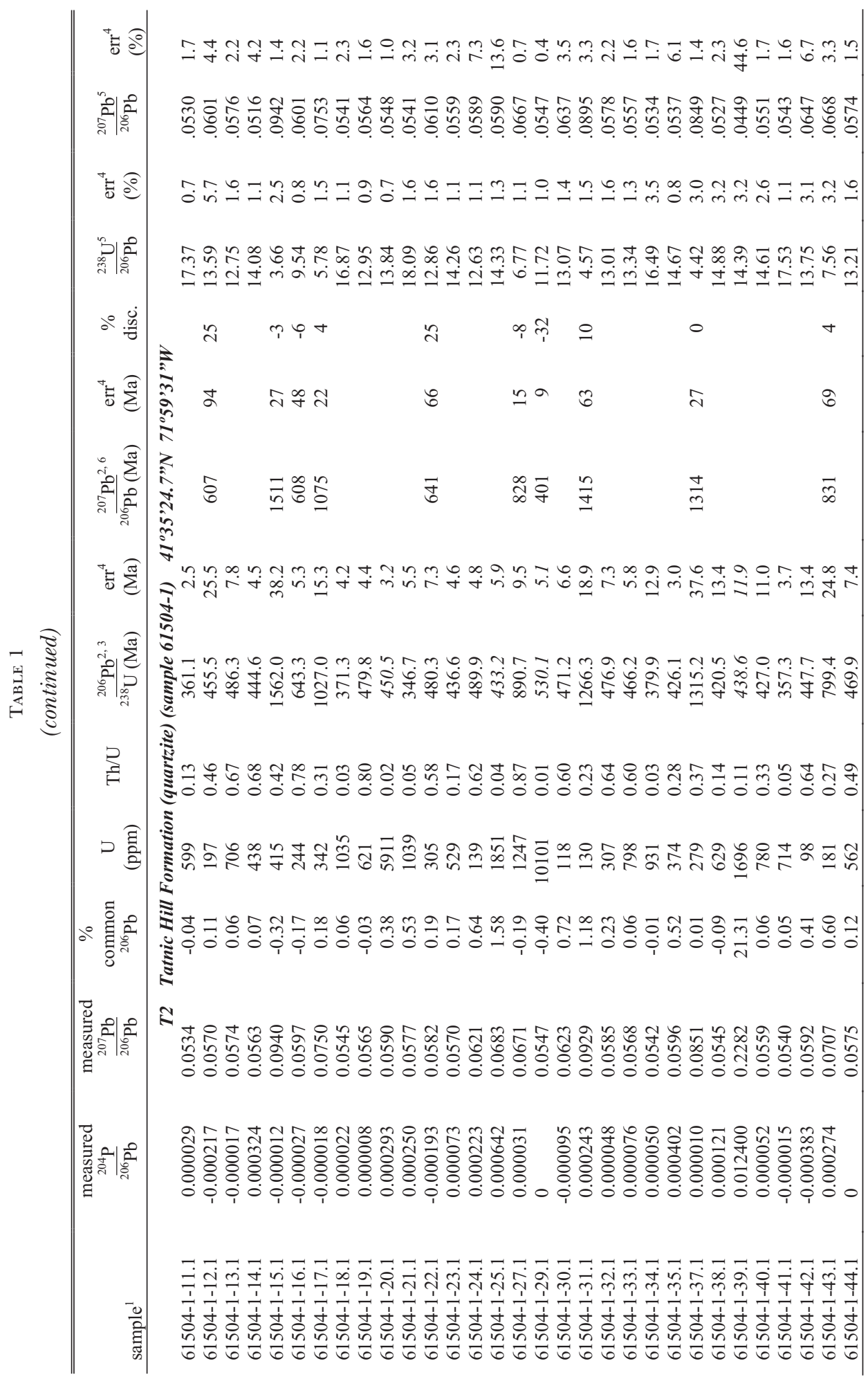


sedimentary rocks in the Merrimack and Putnam-Nashoba terranes, eastern New England 139

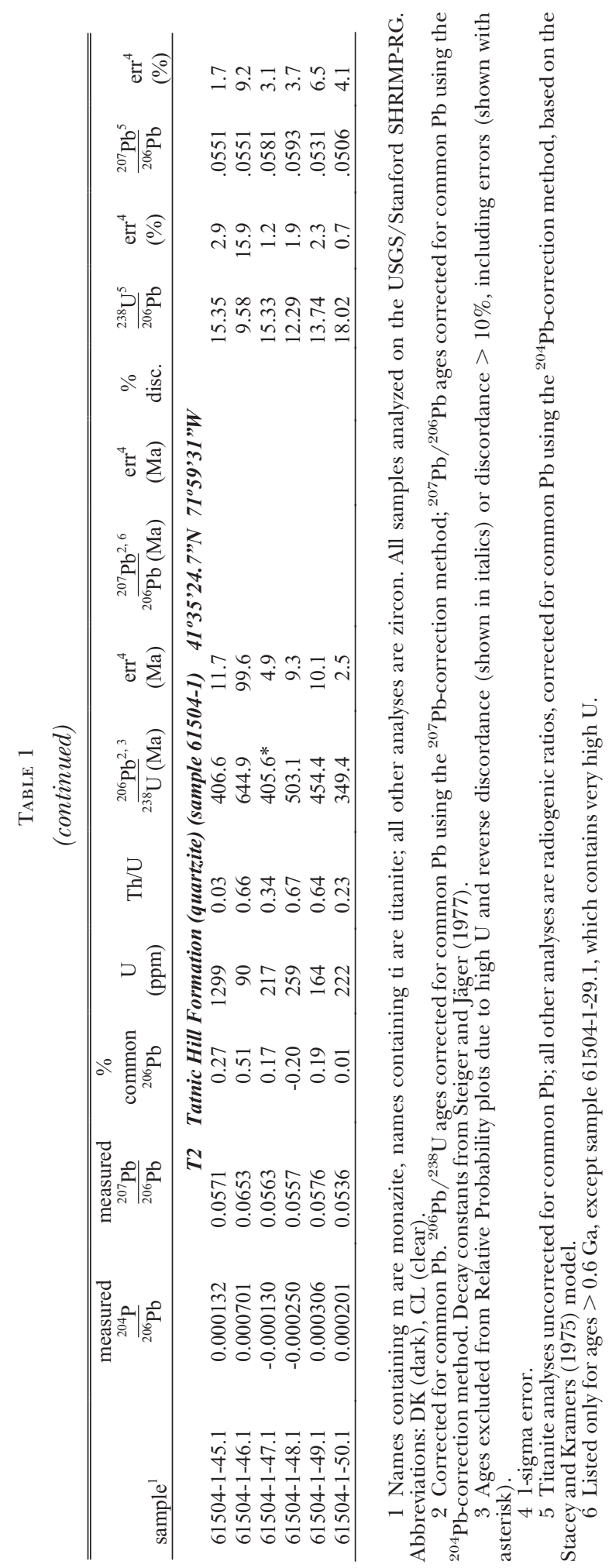




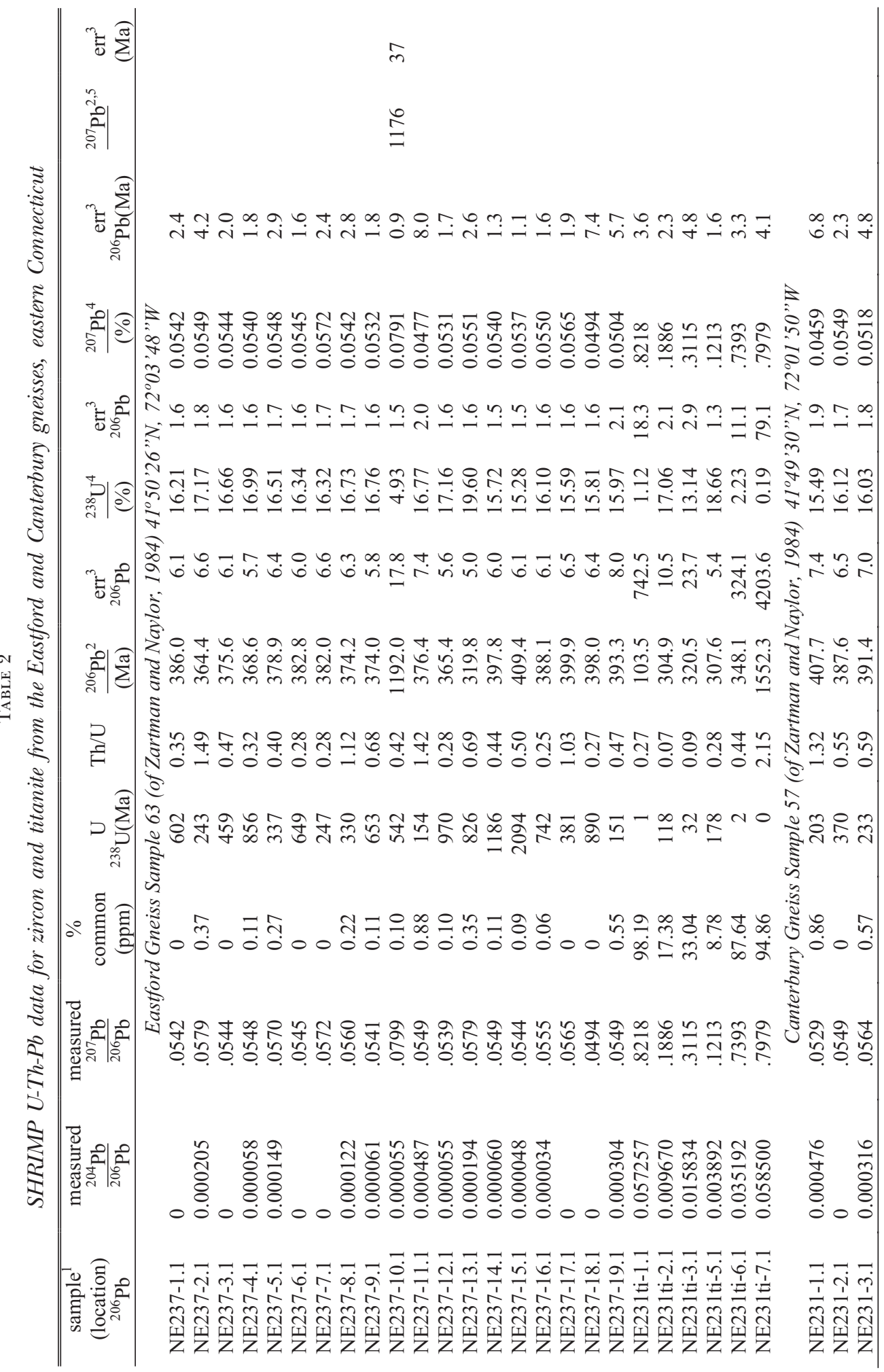


sedimentary rocks in the Merrimack and Putnam-Nashoba terranes, eastern New England 141

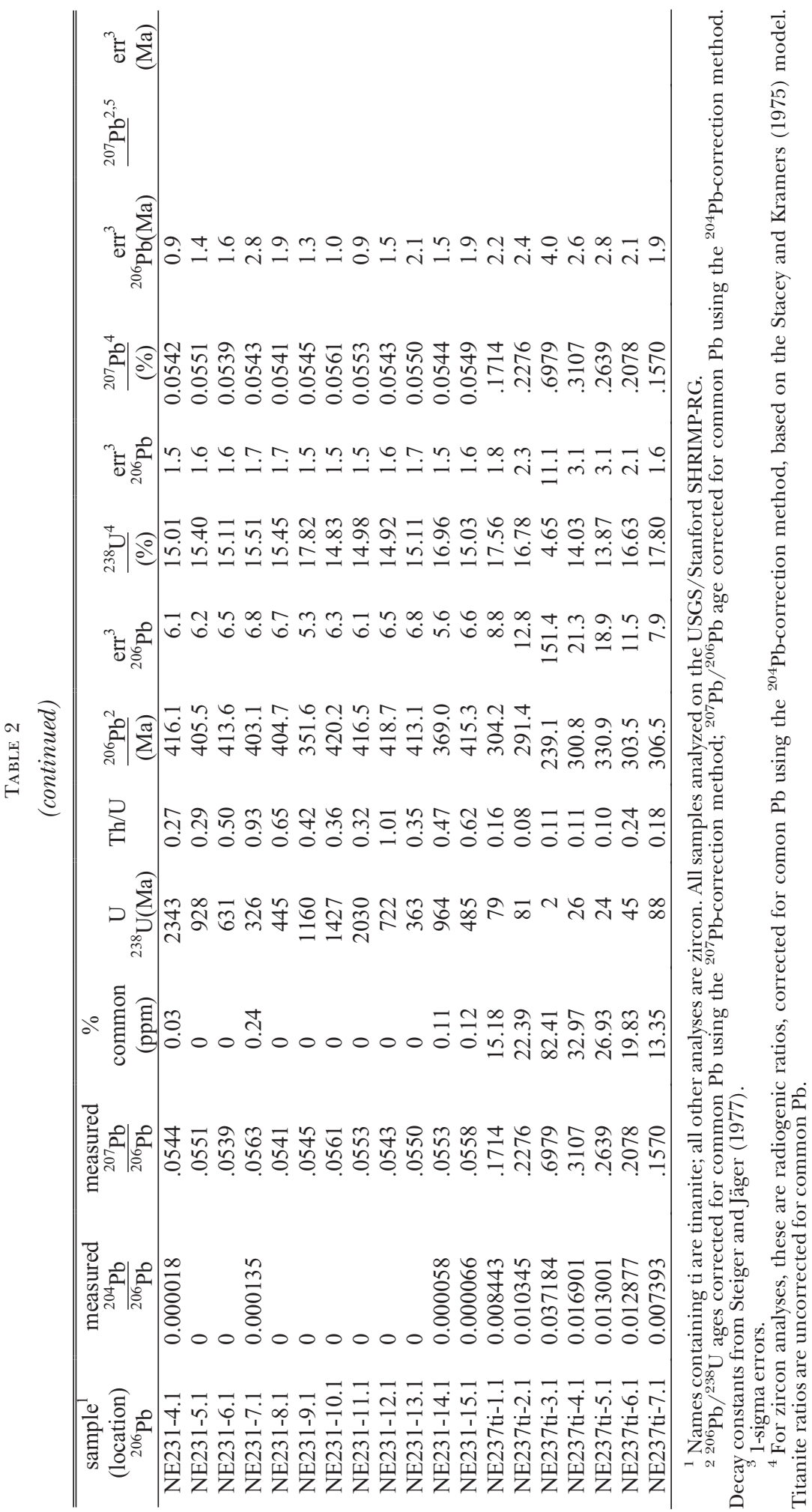


three samples and 20 grains of monazite from a fourth sample were analyzed to establish the times of metamorphism, and thus to constrain the minimum age of deposition of Merrimack terrane sediments. Locations of samples are given below, and in tables 1 and 2.

\section{Merrimack Terrane}

Of the five samples of metasedimentary rocks collected from the Merrimack terrane, three are from units included by Rodgers (1985) within the Hebron Formation of Connecticut. The northern sample (sample H-N, fig. 2) is from an area where the grade of overprinting metamorphism is relatively low but sufficient to reset the ${ }^{40} \mathrm{Ar} /{ }^{39} \mathrm{Ar}$ age of amphibole ( $2310 \mathrm{Ma}$, Wintsch and others, 1993). Samples from the central and southern parts of our study area (H-C and H-S, respectively; fig. 2) are higher in metamorphic grade (Wintsch and others, 2003) and were collected to support mapping by the U.S. Geological Survey in the Essex and Old Lyme 7.5-minute quadrangles (Walsh and others, 2007). Samples of Kittery (K-1) and Berwick (B-1) formations from southern Maine (fig. 3) were collected to test regional correlations within the Merrimack terrane.

Hebron Formation, Connecticut.-The northern Hebron sample (H-N) (Wintsch and others, 2001, stop 4; fig. 2) is composed of thinly bedded purplish biotite schist and olive green hornblende granofels interlayered on a $\mathrm{cm}$ scale. It is deformed into isoclinal folds and intruded by unfoliated plagioclase-rich pegmatites. Oscillatory and sector zoning in cores of detrital zircons separated from this rock are truncated at grain boundaries (fig. 4A), presumably due to mechanical abrasion during transport. Some grains have very thin metamorphic overgrowths, too thin for SHRIMP analysis. Fifty grains were analyzed, 3 of which are discordant and excluded from further analysis. The data define two major groups of ages: (1) 420 to $490 \mathrm{Ma}$, and (2) 900 to 1200, and 1300 to $1920 \mathrm{Ma}$, with a few grains outside these limits. Also present are three Neoproterozoic grains, and two older grains (2.3 and $2.5 \mathrm{Ga}$, table 1; fig. 4D). Thin metamorphic overgrowths were not analyzed.

Titanite from sample H-N was analyzed to determine the time(s) of metamorphism of the eastern belt of Hebron Formation. Two varieties of titanite occur: slightly yellowish brown, and colorless. Both populations have cores and overgrowths as shown by BSE imaging. Most of the yellow-brown grains contain between 10 and $80 \mathrm{ppm} \mathrm{U}$, whereas colorless grains have lower $U$ concentrations (mostly between 5 and 25 ppm; table 1). Both populations have significant concentrations of common $\mathrm{Pb}$, necessitating calculation of regressions through the data to concordia lower intercept ages using analyses that are uncorrected for common $\mathrm{Pb}$. Data were grouped according to location in the grains from both populations, resulting in ages for cores and overgrowths (fig. 4C). The 3-D linear regression (Ludwig, 2003) for cores yields an age of $301 \pm 5 \mathrm{Ma}$, whereas overgrowths formed at $290 \pm 11 \mathrm{Ma}$ (fig. 2C). Although these ages overlap within uncertainty, the difference in ages may be real given the textural relationship of cores inside overgrowths.

Sample H-C of the Hebron Formation contains thick $(10-20 \mathrm{~cm})$ layers of purplish biotite schists and granofels interbedded with pale green hornblende- and diopside-bearing granofels layers, both intruded by plagioclase-rich pegmatites, reflecting upper amphibolite facies metamorphism. Subsequent deformation produced boudins of pegmatites and layers of calcareous granofels, and later deformation refolded these layers. CL images of zircons from H-C shows them to be very similar to zircons in sample H-N. Fifty zircon cores were analyzed, of which six discordant Proterozoic analyses were discarded (table 1; fig. 4E). The data define three major age clusters: (1) about 425 to $480 \mathrm{Ma}$, (2) about 980 to $1270 \mathrm{Ma}$, and (3) about 1480 to 1815 Ma with a few grains outside these limits (table 1). 

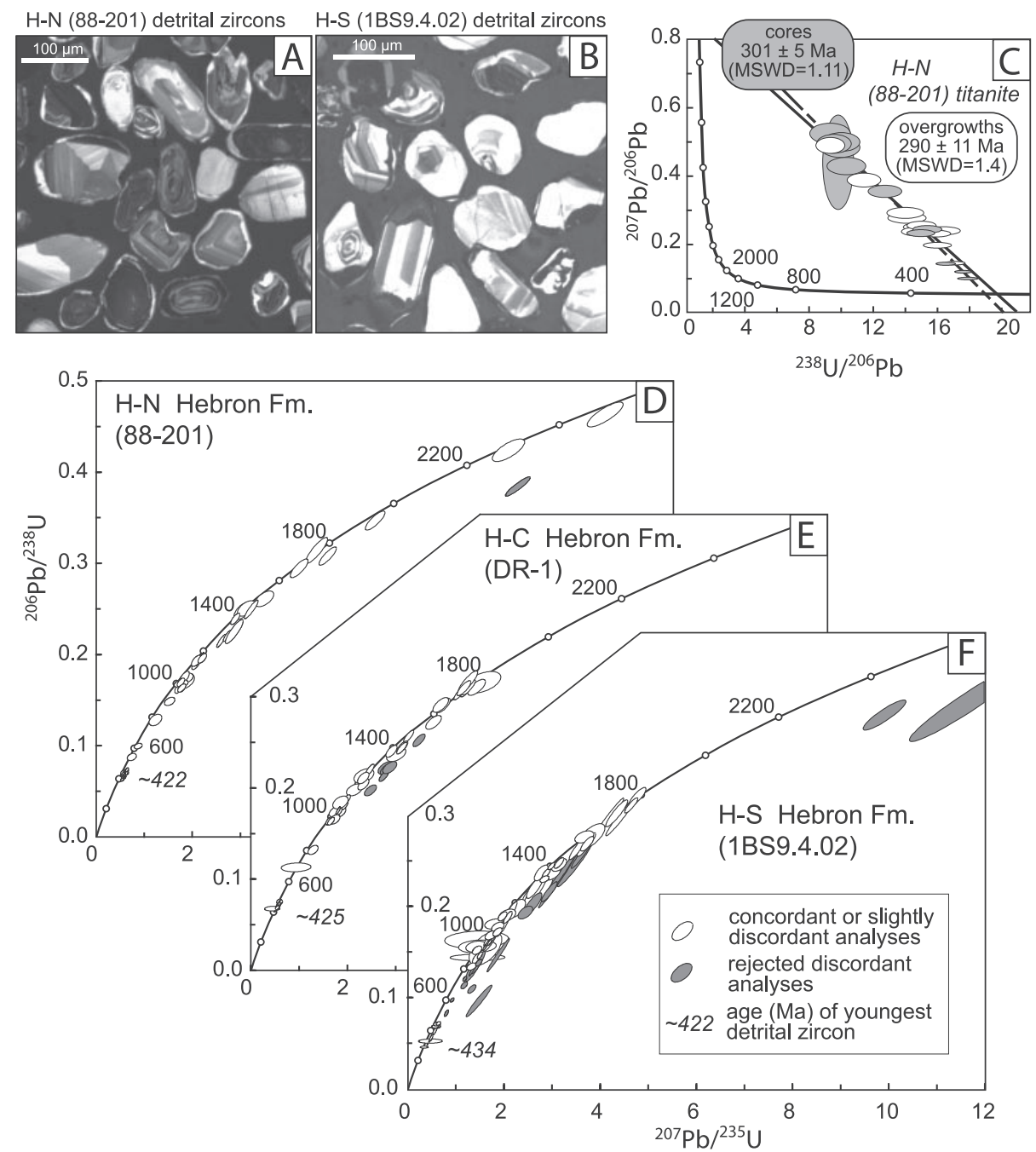

Fig. 4. Images and concordia diagrams showing the results of analyses of zircons from the Hebron Formation of Connecticut (fig. 2). (A) and (B): cathodoluminescent images of zircons from samples H-N and H-S, showing oscillatory and sector zoning in rounded detrital magmatic grains. (C): Terra-Wasserburg diagram showing the U-Pb data from cores and overgrowths in titanites from sample H-N. (D), (E), and (F): concordia diagrams showing the ages and uncertainties of detrital zircons from samples H-N, H-C, and H-S The ages of the youngest detrital grains in each sample are indicated in the lower left corner.

The southern Hebron Formation sample (H-S, fig. 2) is composed of decimeterthick purplish biotite schists interlayered with greenish hornblende or diopside granofels, and is intruded by subsequently foliated, sill-like plagioclase-dominated pegmatites. Both compositional banding and foliation are parallel to the northeast dipping regional foliation. CL imaging of zircons from this sample shows cores with oscillatory zoning overgrown by wide rims as much as a third of the diameter of the cores (fig. 4B). Seventy-six grains were analyzed in two analytical sessions (table 1), of which 18 were discarded due to excessive discordance (fig. 4F). Five analyses of rims (low $\mathrm{Th} / \mathrm{U}$, table 1 ) have ages ranging from about 300 to $360 \mathrm{Ma}$. The remaining 53 grains have ages that define three major age groups: (1) about 430 to $450 \mathrm{Ma}$, (2) 

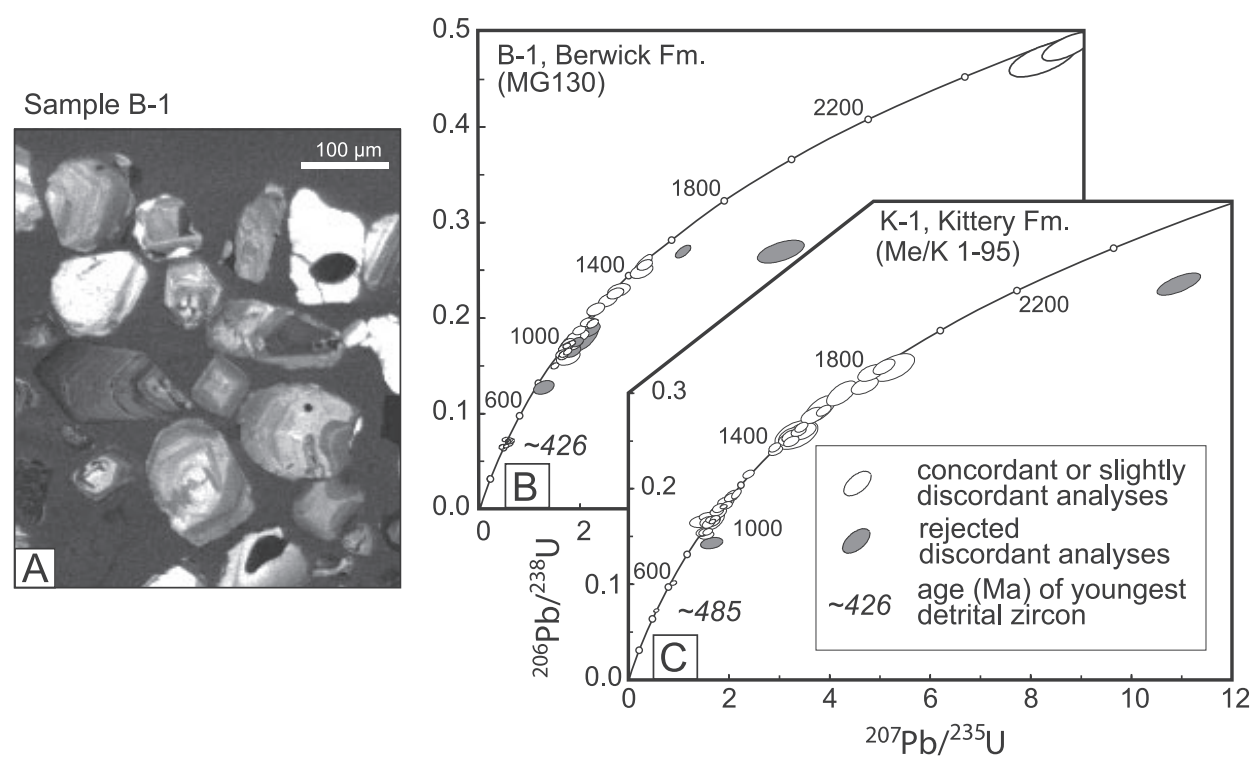

Fig. 5. Cathodoluminescent image of typical zircons in the Berwick Formation (sample B-1), and concordia diagrams showing the results of analyses of zircons from the Berwick and Kittery formations of SW Maine (fig. 3). (A): oscillatory zoning in rounded detrital magmatic zircons from sample B1. (B) and (C): concordia diagrams showing the ages and uncertainties of detrital zircons from samples B-1 and K-1. The ages of the youngest detrital grains in each sample are indicated.

about 800 to $1150 \mathrm{Ma}$, and (3) about 1290 to $1765 \mathrm{Ma}$, with a few grains outside these limits.

Merrimack terrane, Maine.-To test the correlation of rocks assigned to the Merrimack terrane in Connecticut (Hebron Formation) with those assigned to the Merrimack terrane in Maine and New Hampshire, single samples of the Berwick and Kittery formations from rocks in the upper and lower greenschist facies, respectively, were analyzed. CL images of zircons from both samples show grains with oscillatory-zoned domains; very few overgrowths were detected (fig. 5A), as expected from the low metamorphic grade of the rocks. Fifty grains were analyzed from each sample. From the Berwick data, eight discordant analyses were excluded, and two discordant analyses from the Kittery data were excluded. Ages of zircons from the Berwick Formation form three major age groups: (1) about 425 to $475 \mathrm{Ma}$, (2) about 900 to $1435 \mathrm{Ma}$, and (3) about 2600 to $2850 \mathrm{Ma}$ (table 1; fig. 5B). Zircons from the Kittery Formation (table 1; fig. 5C) are mostly between about 925 and $1900 \mathrm{Ma}$, with a gap between $\sim 1200$ and $\sim 1400 \mathrm{Ma}$. Two younger grains are about 485 and $650 \mathrm{Ma}$, whereas 3 older grains are about 2.7 Ga. Although the Berwick and Kittery have similar Proterozoic and Archean age populations, the absence of a significant Paleozoic population and the occurrence of one Neoproterozoic grain in the Kittery Formation suggest that the sediments of these two units had different sources. A transport direction for the Kittery from the east rather than the west, as indicated by paleo- current directions (Rickerich, 1984; Hussey and others, 1984) might explain this difference (see Discussion).

Intrusive Rocks, Connecticut.-The Eastford gneiss intrudes the Hebron Formation in northeastern Connecticut, whereas the Canterbury gneiss intrudes the Hebron in sill-like fashion from extreme northeastern Connecticut to the southwestern end of the Honey Hill fault (Rodgers, 1985; fig. 2). Emplacement ages for these granitic gneisses were determined to constrain the minimum age of deposition of the Hebron Forma- 
tion. The rocks have been previously dated by the Rb-Sr whole-rock method, yielding ages of $416 \pm 23 \mathrm{Ma}$ for the Canterbury Gneiss (Pignolet, and others, 1980; Pignolet, ms, 1981), and $403+28$ and $395+9$ Ma for the Canterbury and Eastford gneisses, respectively (Zartman and Naylor, 1984). Zartman and Naylor (1984) also dated both gneisses by the conventional multi-grain U-Pb method, but the uncertainties of their results were too large to allow age discrimination between the two gneisses, and they reported an aggregate age of $395 \pm 10 \mathrm{Ma}$. Because the uncertainty of these analyses did not adequately constrain the age of intrusion, we reanalyzed zircons using in situ SHRIMP analysis from samples originally described and dated by Zartman and Naylor (1984).

Zircons from the Eastford Gneiss (sample 63 of Zartman and Naylor, 1984) display two morphologies: acicular/prismatic (length-to-width ratio (1/w) of 5-6) and tabular (l/w of 2-3); grains in both populations contain a few small inclusions (fig. 6A). Imaging in CL shows concentric oscillatory zoning; thin dark overgrowths are present on some grains (fig. 6B). Twelve analyses (table 2) yield a coherent age group of $379 \pm$ 4 Ma (fig. 6C). This Late Devonian emplacement age is slightly younger than the results of Zartman and Naylor (1984). One rounded, xenocrystic core is $1192 \mathrm{Ma}$, four ages are slightly older (398-409 Ma), and two ages are younger (364 and $320 \mathrm{Ma}$ ). The latter ages are from oscillatory-zoned rims and likely record the times of metamorphic overgrowth.

Zircons from the Canterbury Gneiss (sample 57 of Zartman and Naylor, 1984) are prismatic (1/w of 3-4) and euhedral; many grains are fractured (fig. 6D). In CL the grains show concentric oscillatory zoning (fig. 6E). Three tabular grains yield ages of 388 to $403 \mathrm{Ma}$; another tabular grain is $369 \mathrm{Ma}$ (table 2). One younger analysis (352 $\mathrm{Ma}$ ) probably is a mixture of core and overgrowth. The other ten grains yield a coherent age group of $414 \pm 3 \mathrm{Ma}$ (fig. $6 \mathrm{~F}$ ), interpreted to be the time of magmatic crystallization.

To establish the age of regional metamorphism that affected both of these granitic gneisses, we analyzed titanite from both rocks. Grains are subhedral to euhedral, contain few if any inclusions, and are not strongly zoned in back-scattered electron imaging (fig. $6 \mathrm{H})$. These titanites contain low concentrations of uranium $(0.2-178$ ppm, mostly between 2 and $90 \mathrm{ppm}$ ) and high concentrations of common $\mathrm{Pb}$ (9 to $98 \%$; table 2), necessitating calculation of the age by regression through data uncorrected for common $\mathrm{Pb}$ to a lower concordia intercept (fig. 6I). Seven analyses of titanite from the Eastford Gneiss yield an age of $307 \pm 9 \mathrm{Ma} ; 6$ analyses of titanite from the Canterbury Gneiss yield an age of $307 \pm 7 \mathrm{Ma}$. A composite isochron through all 13 data points results in a lower intercept age of $305 \pm 5$ Ma (fig. $6 \mathrm{I}$ ).

The $414 \pm 3$ Ma crystallization age of the Canterbury Gneiss overlaps with the Rb-Sr results (Pignolet and others, 1980; Pignolet, ms, 1981) and confirms that the Eastford and Canterbury gneisses differ in age by about $35 \mathrm{~m} . \mathrm{y}$. The composite age of $305 \pm 5 \mathrm{Ma}$ for titanite from the Eastford and Canterbury gneisses is identical within error of the age of titanite cores from Hebron sample H-N (301 $\pm 5 \mathrm{Ma})$, located about $5 \mathrm{~km}$ southwest of the Canterbury Gneiss sample (fig. 2), and is slightly younger that the cooling age of amphibole ( $\sim 310 \mathrm{Ma}$, Wintsch and others, 1993) from the H-N outcrop. These ages indicate that these rocks shared a common metamorphic history since at least the mid-Pennsylvanian.

\section{Putnam-Nashoba Terrane}

Two samples from the Tatnic Hill Formation of the Putnam-Nashoba terrane were analyzed to constrain the age of deposition of this unit (fig. 7). A migmatitic schist (T-1; field number 31903-2) sampled near the mapped stratigraphic top of the lower member of the formation (Dixon, 1964) yielded zircon grains with patchy or faint oscillatory zoning in cores and dark (in CL) unzoned overgrowths. Forty cores were 

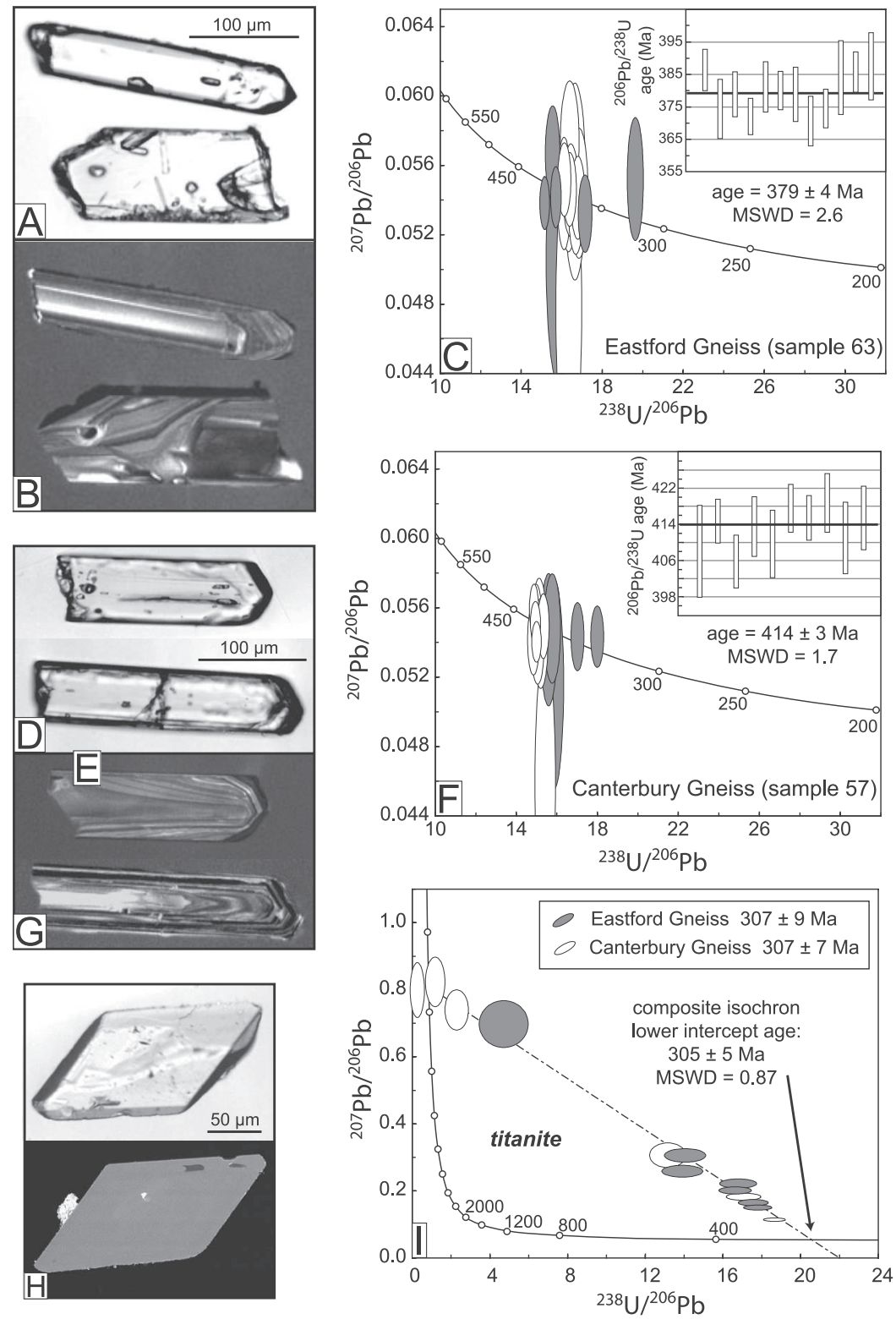

Fig. 6. Summaries of U-Pb data from the Eastford and Canterbury gneisses. Transmitted light (A) and CL (B) images, and a concordia diagram with a weighted average plot (C) showing zircons analyzed from the Eastford Gneiss, sample 63. Transmitted light (D) and CL (E) images, and a concordia diagram with a weighted average plot (F) showing zircons analyzed from the Canterbury Gneiss. Transmitted light $(\mathrm{G})$ and back-scattered electron $(\mathrm{H})$ images of titanite from the Canterbury Gneiss. (I): a Terra-Wasserburg diagram comparing the isotopic compositions of titanite grains from the Canterbury and Eastford gneisses.

analyzed (table 1) of which 6 yielded highly discordant ${ }^{206} \mathrm{~Pb} /{ }^{238} \mathrm{U}$ ages from grains of probable Mesoproterozic or Neoproterozic age. Of the remaining 34 analyses, 30 define an age range of 383 to $434 \mathrm{Ma}$ with a peak on the relative probability curve corresponding to $\sim 400 \mathrm{Ma}$ (fig. 8), and have very low $\mathrm{Th} / \mathrm{U}$ ratios typical of a 


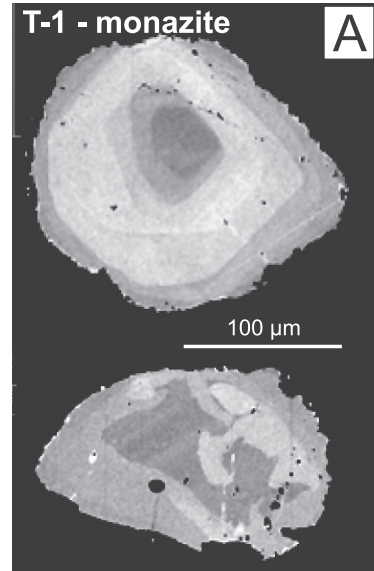

31903-2 Tatnic Hill Fm. monazite

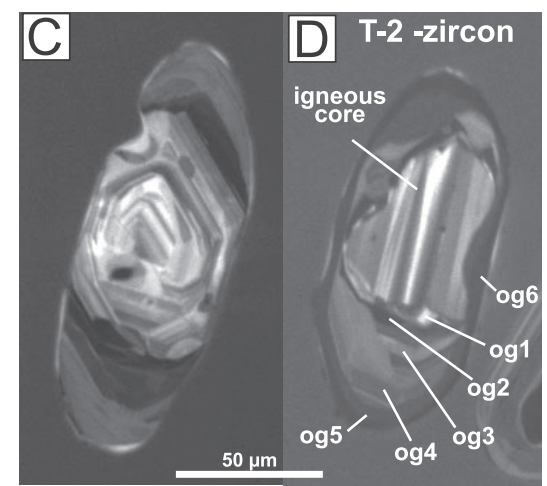

61504-1 Tatnic Hill Fm. detrital zircon
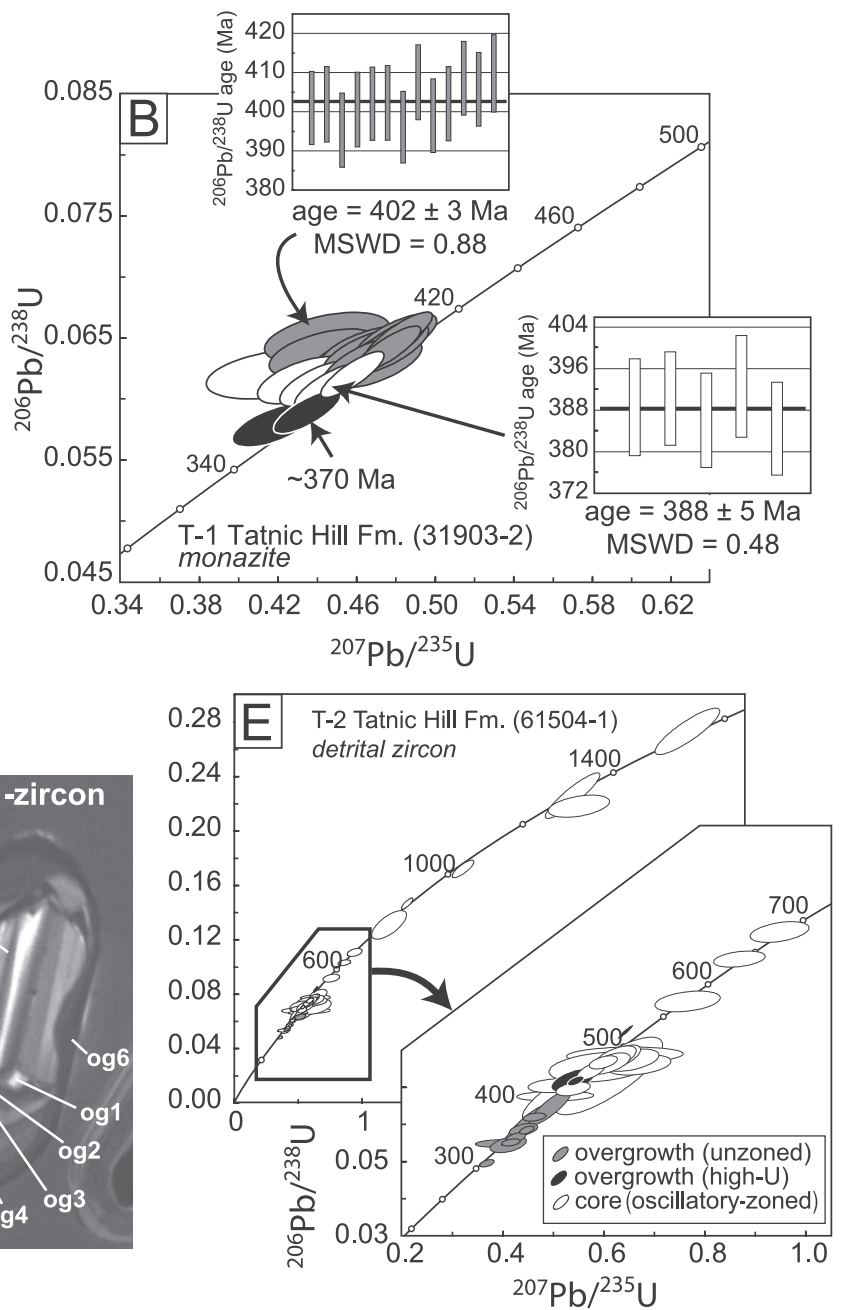

Fig. 7. Images and concordia diagrams showing results from the Tatnic Hill Formation. (A): BSE images of monazites from migmatitic sample T-1 showing multiple overgrowths. (B): summary of age data and weighted average plots from cores (gray), mantles (white) and rims (black) of monazites from sample T-1. (C) and (D): CL images of zircons from quartzite sample T-2, showing magmatic oscillatory zoned cores, and up to 6 metamorphic overgrowths (og). (E): a concordia diagram summarizing the age data from detrital zircons from sample T-2, with an enlargement.

metamorphic origin. Only one grain (31903 - 2-8.1, $490 \mathrm{Ma}$ ) has a Th/U suggestive of a magmatic origin (table 1), while three other analyses have ages of about 484 to 489 $\mathrm{Ma}$, but also have very low $\mathrm{Th} / \mathrm{U}$ of 0.08 . Co-existing monazite from this sample has a complicated growth history as revealed by BSE images that show cores with multiple overgrowths (fig. 7A). Pale yellow and medium yellowish-brown varieties (light, lt, and dark, dk grains, respectively, table 1) were found, and yielded indistinguishable results. Thirteen analyses of monazite cores of both colors result in an age of $402 \pm 3 \mathrm{Ma}$, while 5 analyses of overgrowths yield a younger age of $388 \pm 5 \mathrm{Ma}$. Two analyses are younger at about $370 \mathrm{Ma}$ (fig. 7B). These results from associated monazite make the history of the zircons in sample T-1 clearer. The peak in the age probability of zircons at $\sim 400 \mathrm{Ma}$ 


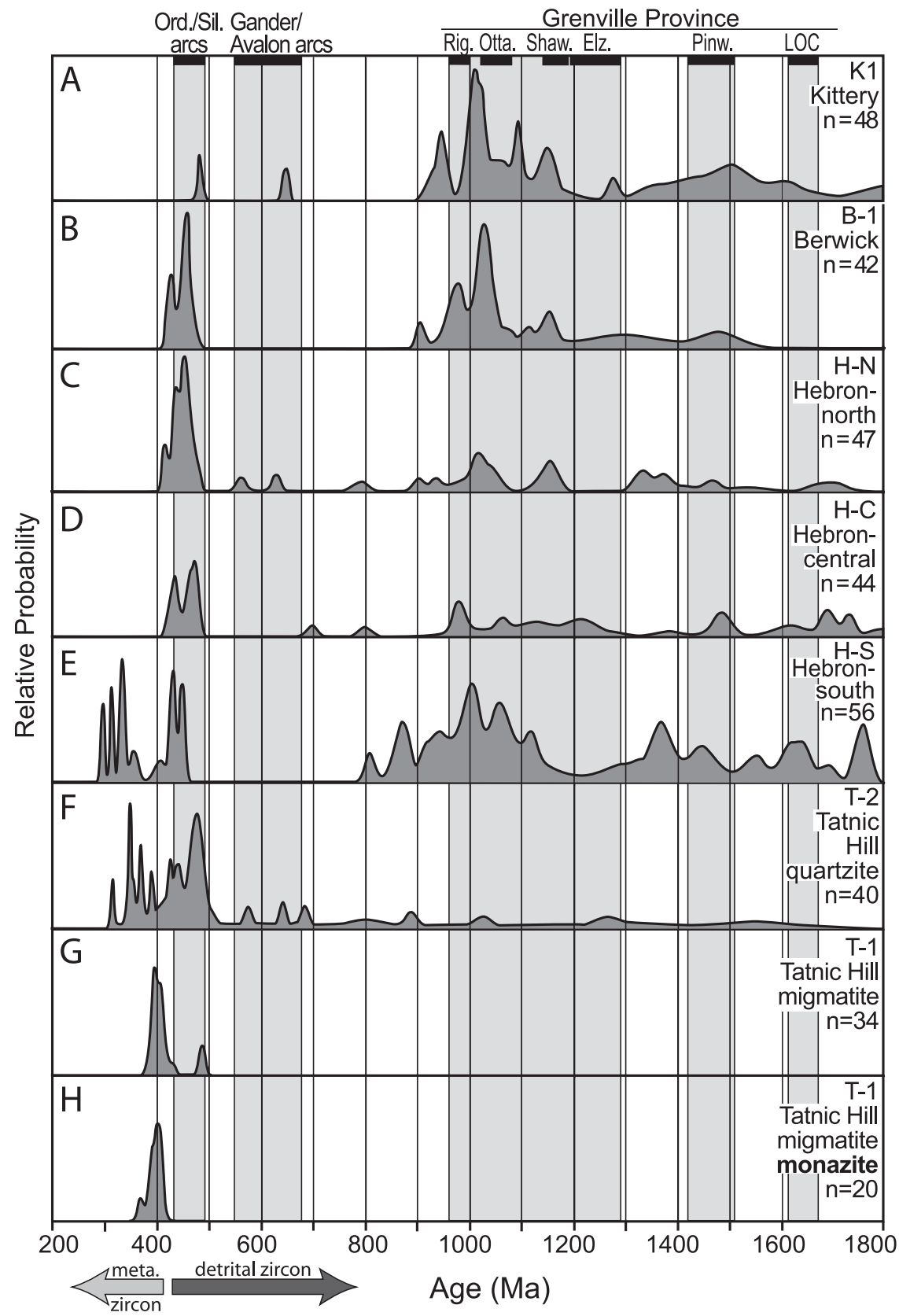

Fig. 8. A comparison on relative probability plots of all concordant zircon (figs. A-G) and monazite (fig. $\mathrm{H}$ ) ages analyzed in this study. Relative probabilities are calculated for each sample, with number of grains in the calculation indicated. The ranges of ages for Ordovician arcs, Gander and Avalon arcs, and Grenvillian orogenic stages are shown by gray bars. Dark gray and light gray arrows indicate respectively that grains older than $\sim 425 \mathrm{Ma}$ are detrital, and grains and overgrowths younger than $\sim 405 \mathrm{Ma}$ are metamorphic. Abbr.: Rig., Rigolet; Otta., Ottawan; Shaw., Shawinigan; Elz., Elzevirian; Pinw., Pinwarian; LOC., Labradorian orogenic cycle. 
coincides with the dominant age of the monazite, together indicating a high grade event at this time. Despite the very diffuse oscillatory zoning in the cores, these zircon grains, though typical of neither magmatic nor metamorphic grains (Corfu and others, 2003), are a consequence of high-grade metamorphic growth. Such an interpretation is consistent with the low $\mathrm{Th} / \mathrm{U}$ ratios commonly found in zircons of metamorphic origin.

To obtain information about the provenance and depositional history of the unit, we collected a second sample, a quartzite (T-2, field number 61504-1) from near the base of the Tatnic Hill Formation (fig. 2) in the hope that the silica-rich bulk composition would have limited anatexis, and thus also zircon recrystallization in this sample. This experiment was apparently successful, because the sample yielded detrital zircons with well-preserved igneous cores, showing oscillatory zoning patterns in CL (fig. 7C). Nevertheless, up to six generations of apparently metamorphic overgrowths are present on some grains (fig. 7D), some with internal oscillatory or sector zoning, and some dark (in CL) and unzoned, indicating that zircon did recrystallize in these rocks as well. Thus, the rounded tips and edges of these zircons that are typical of detrital origin could also be explained by partial dissolution in an anatectic fluid. Three different internal zones of these zircons as revealed by CL analysis were analyzed: (1) oscillatory-zoned cores, (2) medium to dark gray (in CL) overgrowths, and (3) wholly metamorphic grains containing very high-U (black in CL) unzoned cores and high-U (dark gray in CL) mantles and rims. Because the black cores in some grains are partially resorbed, it is likely that these metamorphic zircons formed during at least two separate periods of growth.

A total of 50 grains were analyzed, including 31 analyses of magmatic cores (2 excluded due to unreasonably young ages probably caused by Pb-loss through cracks), 8 analyses of overgrowths (one excluded because the SHRIMP spot overlapped two age zones, and another excluded due to discordance), and 11 analyses of metamorphic grains. Ages of cores fall mostly between $\sim 425$ and $500 \mathrm{Ma}$, with 6 Neoproterozoic ages (about $575-900 \mathrm{Ma}$ ) and 4 Mesoproterozoic ages (about $1.0-1.5 \mathrm{Ga}$; table 1, fig. 7E). Ubiquitous overgrowths on igneous cores range in age from about 315 to $390 \mathrm{Ma}$, suggesting that this rock was affected by multiple episodes of metamorphic zircon growth spanning 75 m.y.

\section{DISCUSSION}

\section{Correlation of Units}

Hebron Formation.-To assess the stratigraphic correlation of metasedimentary rocks assigned to the Merrimack terrane (see for example, Hibbard and others, 2006), we compare the distribution of zircon ages on the relative probability plots of figure 8 . The results show that detrital zircon age distributions in three samples from the Hebron Formation of eastern Connecticut are very similar (figs. 8C, D, and E). All three samples share a population from $\sim 800$ to $1200 \mathrm{Ma}$, and smaller populations between 1300 and 1750. They also share large bimodal populations of Ordovician and Early Silurian magmatic grains (38\% in sample H-N), and few or no grains in the range 550 to $800 \mathrm{Ma}$. Thus, we conclude that these rocks were derived from similar sources. The combination of similar lithologies, similar detrital zircon age populations, and stratigraphic continuity along a single strike belt supports the correlation of these three samples as belonging to a single unit: the Hebron Formation.

Berwick Formation. - Detrital zircons from the Berwick Formation from southern Maine share most age populations with zircons from the Hebron Formation in Connecticut (fig. 8B). Berwick zircons have a significant age population between 900 and $1200 \mathrm{Ma}$, and a smaller population between 1400 and $1500 \mathrm{Ma}$. Also present is a large, bimodal Ordovician and Silurian age population (21\% of the grains), whereas a 
late Neoproterozoic population is lacking. The strong similarities of age populations support the correlation of the Berwick and Hebron formations.

Kittery Formation. - Age populations of detrital zircons from the Kittery Formation differ from other samples of Merrimack terrane rocks (fig. 8A). Similarities include a large Mesoproterozoic age population with a major peak near $1000 \mathrm{Ma}$, and a very small population (a single grain) between 550 to $650 \mathrm{Ma}$ (fig. 8). However, we found only a single Ordovician grain in the Kittery Formation sample, rather than the major bimodal Ordovician and Silurian peaks present in the Berwick and Hebron samples (table 1). We consider the lack of Ordovician/Silurian grains in the Kittery Formation to be significant because it makes a correlation with the other samples doubtful while constraining its provenance.

Putnam-Nashoba terrane.-The migmatitic sample of the Tatnic Hill Formation (T-1) provides only discordant ages not useful for the determination of provenance. However, the quartzite sample (T-2) does contain detrital zircons with a range of ages. The provenance of these sediments is dominated by Ordovician and Silurian sources $(48 \%)$, with only minor Mesoproterozoic and Neoproterozoic components. These results are distinct from the other samples in our study, and support the identification of rocks of the lower member of the Tatnic Hill Formation as distinct from the Hebron Formation, an interpretation already made on the basis of differences in lithology, stratigraphy, and metamorphic grade (Dixon, 1964; Snyder, 1964).

\section{Age of Deposition}

The maximum age of deposition of a metasedimentary rock is constrained to be younger than the age of the youngest detrital (magmatic?) zircon population, and older than the oldest metamorphic overgrowth. To help discriminate between zircons of magmatic and metamorphic origins, ages of individual zircons from all metasedimentary samples are compared with their $\mathrm{Th} / \mathrm{U}$ ratios in figure 9 . Note that almost all (magmatic) grains with $\mathrm{Th} / \mathrm{U}>\sim 0.1$ are Silurian or older, while (metamorphic) grains with $\mathrm{Th} / \mathrm{U}<0.1$ are Devonian or younger (Hoskin and Schaltegger, 2003). This distinction makes the comparison of detrital magmatic and metamorphic grains less ambiguous.

Hebron and Berwick formations. - The youngest zircons in Hebron samples H-N, $\mathrm{H}-\mathrm{C}$, and $\mathrm{H}-\mathrm{S}$ are 423,425 , and 434 (all $\pm 9 \mathrm{Ma} 2 \sigma$ ), respectively. The minimum age of zircon found in the Berwick Formation is $426 \pm 9 \mathrm{Ma}(2 \sigma)$. Because these four samples are considered to be correlative on stratigraphic and provenance grounds, it is reasonable to compare the ages of their detrital grains collectively. Thus, these samples have a minimum age of $\sim 425 \mathrm{Ma}$ (table 1 ; fig. 9 ), which establishes the maximum age of the original sediments as Wenlockian (fig. 10). In eastern Connecticut, the $\sim 414 \mathrm{Ma}$ Canterbury Gneiss (see Results) intrudes the Hebron Formation (fig. 2). Thus the Hebron Formation is Late Silurian to earliest Devonian, probably Ludlovian, and the overlying Scotland Schist (fig. 2; Snyder, 1964) is slightly younger (fig. 10). In Massachusetts and southern New Hampshire, the 418 Ma Newburyport complex (Fargo and Bothner, 1995) intrudes the Kittery, and by structural inference (see Provenance below) also the Berwick Formation, thus limiting the age of the Berwick unit to no younger than Wenlockian to Ludlovian (fig. 10). By correlation, the age of deposition of both the Hebron and Berwick formations is Late Silurian, and probably Ludlovian, eliminating the possibility that these rocks might be Ordovician, as proposed by Rodgers (1985) and Lyons and others (1997) in Connecticut and New Hampshire, respectively.

Kittery Formation.-The age and stratigraphic position of the Kittery and Eliot formations with respect to the Berwick is still contested in the literature. Relative to the Berwick Formation, they may be younger (see for example, Lyons and others, 1997), or they may be older (for example, Robinson and Goldsmith, 1991; fig. 10). The single 


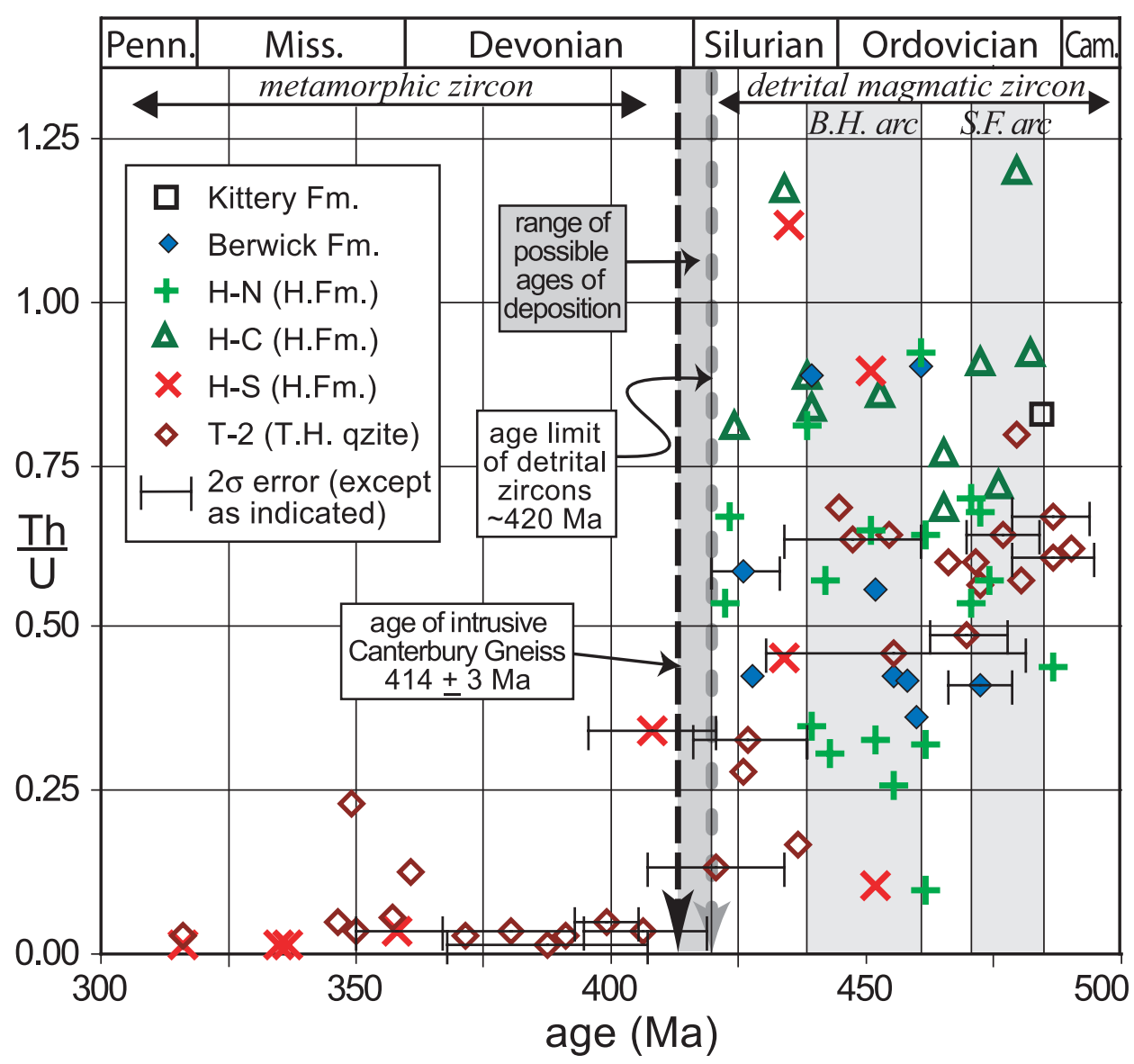

Fig. 9. A comparison of the ages and $\mathrm{Th} / \mathrm{U}$ ratios of detrital Paleozoic zircon cores and metamorphic overgrowths analyzed in six of seven samples in this study. Sample T-1, with abundant metamorphic zircons with ages of $\sim 400 \mathrm{Ma}$, is omitted for clarity. Magmatic zircons tend to have $\mathrm{Th} / \mathrm{U}$ ratios $>0.10$, while metamorphic zircons have ratios $<0.1$. The minimum age limit of detrital magmatic zircons at $\sim 420 \mathrm{Ma}$ (dashed gray line), and the age of the intrusive Canterbury Gneiss (414 $3 \mathrm{Ma}$, dashed black line) are indicated. Between them the range of possible depositional ages is indicated between the dashed lines. Gray bands showing the ranges of known ages of Early Ordovician (Shelburne Falls, S.F.) and Late Ordovician (Bronson Hill, B.H.) arcs lie behind data from most samples, showing the likelihood that these arcs provided detrital zircons to these samples.

Paleozoic grain identified in the Kittery sample (K-1, $\sim 485 \mathrm{Ma})$ provides only an unsurprising Early Ordovician limit to the maximum age of this unit. The ages of plutons that intrude the Kittery Formation (fig. 3), the Exeter diorite (406 $\pm 1 \mathrm{Ma}$; Bothner and others, 1993) and the Newburyport quartz diorite (418 $\pm 1 \mathrm{Ma}$, Fargo and Bothner, 1995; fig. 10) that includes Kittery xenoliths within it (Bellini and others, 1982) define the minimum age of the Kittery to be latest Silurian. Thus the time of deposition is broadly constrained to be between Early Ordovician and Late Silurian. However, with 48 grains analyzed, there is a 95 percent confidence that no population $>10$ percent of the total population was missed (Vermeesch, 2004). Given the typically $>20$ percent fraction of Ordovician-Silurian grains in the Hebron and Berwick samples, the lack of grains found in this age range in the Kittery probably reflects a real absence. The simplest explanation for the absence of this population is that the Kittery Formation is older than Late Silurian (see Provenance below). 


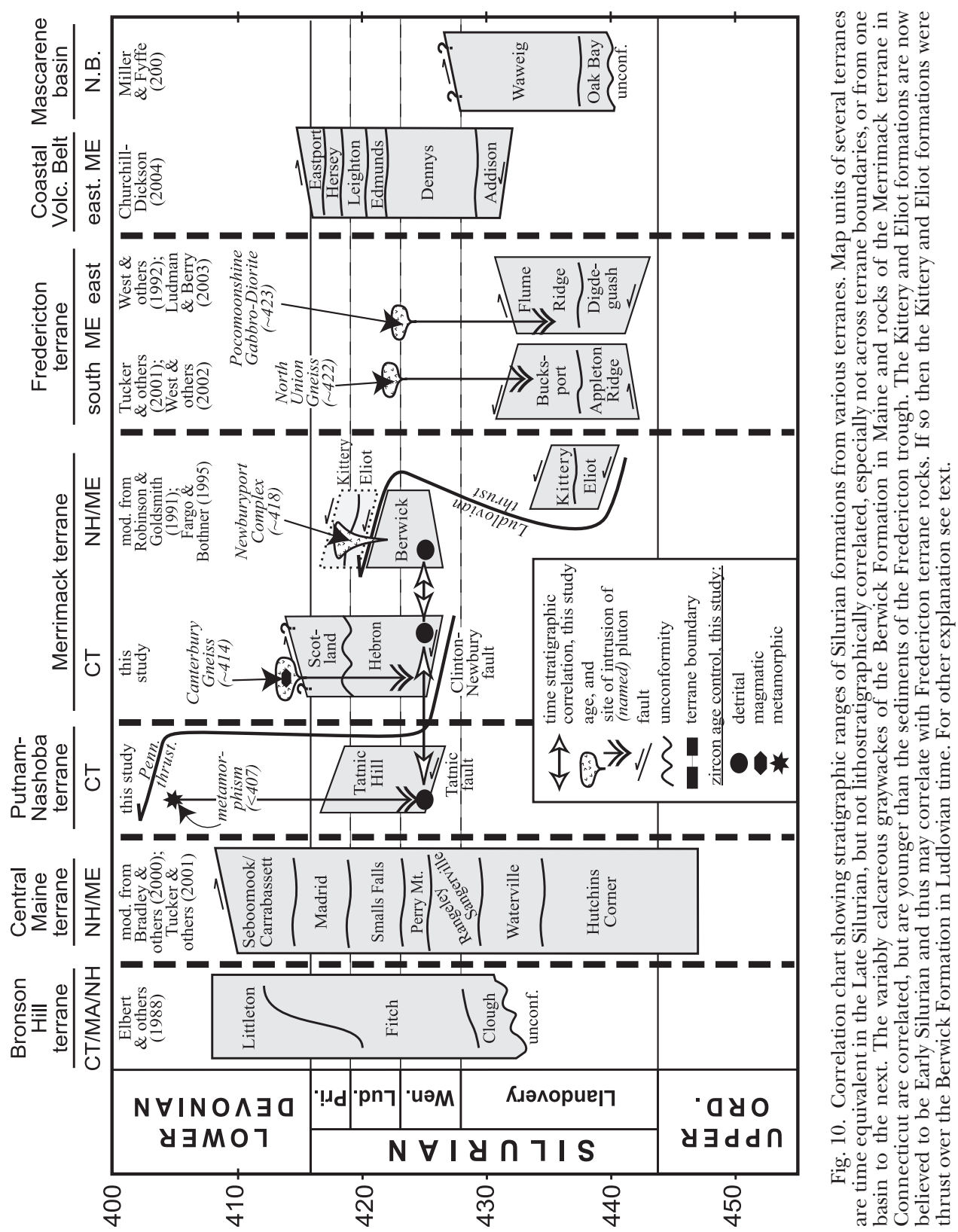


Putnam-Nashoba Terrane, Tatnic Hill Formation.-The age of the youngest two detrital zircons from a quartzite in Tatnic Hill Formation $(\sim 426 \mathrm{Ma})$ constrain the maximum time of deposition to be Wenlockian or younger (table 1), similar to the Hebron/Berwick rocks of the Merrimack terrane. The minimum age of deposition of these rocks is constrained by the oldest ages of metamorphic overgrowths on detrital zircon. The ages of overgrowths in both migmatitic sample T-1 and in quartzite sample T-2 are as old as $\sim 408 \mathrm{Ma}$ (Early Devonian). Given that it takes time to establish these anatectic metamorphic conditions regionally (see Age of Metamorphism below), deposition of the original Tatnic Hill Formation sediments must have occurred at the beginning of the $\sim 20$ m.y. time interval available between 426 and 408 Ma. Thus, the original sediments were probably deposited shortly after $426 \mathrm{Ma}$, in late Wenlock or early Ludlow times. The previous age assignments of Ordovician and Neoproterozoic (Rodgers, 1985; Goldsmith, 1991b) are superseded by these new isotopic data supporting a Late Silurian depositional age.

\section{Provenance}

Information on the provenances of metasedimentary rocks of this study is important because sources and net transport directions have significant implications for tectonic reconstructions. The ages of detrital zircons presented in table 1 and summarized in figure 8 allow some inferences about provenance. However, the data from individual samples are not abundant, and some smaller age populations may have been missed (for example, Vermeesch, 2004). The interpretation of provenance is further compromised by the possibility of sedimentary recycling (for example, Bream and others, 2004; Eriksson and others, 2004; Thomas and others, 2004); the implications of this are discussed below. In our study with $\sim 45$ grains analyzed per sample, there is a 95 percent confidence that no fraction constituting greater than $\sim 10$ percent of the population was missed (Vermeesch, 2004). Thus compelling features of the data are that: (1) Mesoproterozoic and Ordovician-Silurian grains are abundant, and (2) Neoproterozoic grains are rare. We discuss the Hebron and Berwick formations as a group because they are likely to have had similar sources and similar ages of deposition (see above).

Grenville Province.-All of our samples have major Proterozoic populations, but the true number of Proterozoic grains is under represented because discordant grains (table 1) are not included in the relative probability plots (fig. 8). Many Proterozoic age clusters overlap with well-established events in the Grenville province, including the Rigolet pulse (980 - $1000 \mathrm{Ma})$, Ottawan pulse $(1020-1080 \mathrm{Ma})$, Shawinigan pulse $(1140$ - $1190 \mathrm{Ma})$, Elzevirian orogenic cycle $(1190$ - $1290 \mathrm{Ma})$, Pinwarian orogeny $(1420$ - $1510 \mathrm{Ma})$, and the Labradorian orogenic cycle $(1610-1670 \mathrm{Ma}$; see fig. 8; from Rivers, 1997). Many grains in our samples have ages between 950 and $1200 \mathrm{Ma}$, corresponding to the youngest three pulses of the Grenville orogeny, and other grains overlap with the Pinwarian orogeny and the Labradorian orogenic cycle; only grains of Elzevirian age are uncommon. Rocks overlapping these ages are common throughout the Grenville province of Canada including inliers in Long Range Mountain, Newfoundland (Rivers, 1997), the Adirondacks (for example, Hamilton and others, 2004), and the northern (for example, Walsh and others, 2004) and southern Appalachians (for example, Aleinikoff and others, 2004; Tollo and others, 2004). Rocks with ages between 1400 and $1500 \mathrm{Ma}$ are most common in southern Labrador (Tucker and Gower, 1994) but are also present in the Georgian Bay area (Rivers, 1997) and throughout southwestern North America (Nourse and others, 2005). Smaller but significant populations in the age ranges of 1300 to 1400 and 1700 to $1800 \mathrm{Ma}$ are also present in some samples. Rocks with ages of 1300 to $1400 \mathrm{Ma}$ (samples H-C and H-S) are not common in the northern Grenville province but do occur in Connecticut (Walsh and others, 2004), Vermont, the southern Adirondacks, and southern Quebec 
(Ratcliffe and others, 1991; Rivers, 1997). A few grains between 1700 and 1800 Ma are present in samples H-C and H-S. The largest source for zircons of this age is the western U.S., but they also occur to the NW in the Georgian Bay area (Rivers, 1997). Thus, all of the detrital zircon ages found in our samples, whether eroded from Proterozoic rocks as first cycle sediments or reworked from eroding early Paleozoic sediments can be explained by derivation from Laurentian sources: the Grenville province and its inliers. An eastern (that is, Gondwanan or Amazonian) source for Mesoproterozoic grains has been proposed for Gander and Avalon terrane rocks (van Staal and others, 1996; Thompson and Bowring, 2000; Barr and others, 2003; Walsh and others, 2007). However, these terranes are unlikely sources for the Hebron, Berwick, and Tatnic Hill formations because these eastern terranes generally lack evidence of magmatic activity of the Labradorian orogenic cycle in the 1600 to $1700 \mathrm{Ma}$ age range (Tassinari and Macambira, 1999; Tassinari and others, 2000), a range containing 4 percent of our grains.

Ordovician Arcs. - The largest age population common to most samples spans the Ordovician and Silurian (fig. 8). The distribution of ages ranges from $\sim 425$ to $490 \mathrm{Ma}$, with most samples containing both Ordovician and Silurian grains but with variable $\mathrm{Th} / \mathrm{U}$ (fig. 9). Rocks of this age range occur within peri-Laurentian and periGondwanan arc systems from Maritime Canada to southern New England (see Hibbard and others, 2006). Peri-Laurentian magmatic rocks with ages in the range $\sim 490$ to $435 \mathrm{Ma}$ (summarized in van Staal, 2007) have been found in the Notre Dame subzone of Newfoundland (for example, Zagorevski and others, 2006, 2007), and in New England, including the Shelburne Falls arc (fig. 9; for example, Sevigny and Hanson, 1993; Ratcliffe and others, 1997; Karabinos and others, 1998; Moench and Aleinikoff, 2003; fig. 9). Magmatic arc rocks of the Gander margin, including the Victoria arc and the Exploits back-arc basin in Newfoundland range in age more broadly from $\sim 510$ to $455 \mathrm{Ma}$ (for example, McNicoll and others, 2003; ValverdeVaquero and others, 2006). In eastern New England they occur in the Middle Ordovician as volcanic rocks in the Casco Bay Group in coastal Maine $(\sim 470 \mathrm{Ma}$, Hussey and others, 1993; Tucker and others, 2001; Hussey and Berry, 2002; Hussey and Marvinney, 2002; West and others, 2004). In southern New England, Gander-derived arc rocks (Aleinikoff and others, 2007) occur in the Late Ordovician-Silurian 460 to $440 \mathrm{Ma}$ age range as the Bronson Hill and Killingworth arcs and Oliverian plutonic suite (fig. 9; Tucker and Robinson, 1990; Aleinikoff and others, 2002; Moench and Aleinikoff, 2003).

Silurian Arcs. - A smaller but significant number of detrital grains are Silurian; potential source rocks younger than $\sim 440 \mathrm{Ma}$ are not common in possible provenance areas to the west. Silurian intrusive rocks occur in the Connecticut Valley terrane (Sevigny and Hanson, 1993), but their intrusive relationships in high-grade metamorphic rocks (Walsh and others, 2004) makes it doubtful that they were exposed at the surface during the Silurian. More likely sources for Silurian detrital zircon are rocks associated with the Coastal Volcanic Belt of Massachusetts, Maine, and New Brunswick (figs. 1 and 3), a bimodal suite of intrusive and extrusive rocks (Hogan and Sinha, 1989) ranging in age from Early Silurian to Early Devonian (for example, Shride, 1976; Miller and Fyffe, 2002; see Moench and Aleinikoff, 2003).

Neoproterozoic Arcs. - Of particular significance in the detrital zircon age populations of figure 8 is the lack of grains with ages between $\sim 750$ and $550 \mathrm{Ma}$. In fact, only 9 of 316 detrital grains analyzed fall in this age range, four of which are from the quartzite from the Tatnic Hill Formation (sample T-1). This absence is surprising in that Late Neoproterozoic rift-related magmatic rocks commonly occur along the western margin of the Appalachians (for example, Cawood and others, 2001), between the Connecticut Valley-Gaspé terrane and the Grenville province. Moreover, blocks of 
Neoproterozoic crustal rocks of the Gander terrane containing abundant 650 to 550 Ma rocks (van Staal and others, 1996; Thompson and Bowring, 2000; Barr and others, 2003) were actively accreting to Laurentia and to each other in the late Silurian (van Staal, 2007; Aleinikoff and others, 2007), suggesting that they might have been proximal to the Merrimack depositional basin. Perhaps the simplest explanation for the lack of Neoproterozoic zircons is that the Gander terrane was being buried by Ordovician (?) and Silurian sediments and was thus not exposed and could not have shed sediments.

Summary.-The similarity of detrital zircon ages in most Merrimack terrane samples, including large Mesoproterozoic and Ordovician age populations, as well as very few late Neoproterozoic grains, indicates a common provenance for all of these rocks. The likely provenance area for most grains is from the west (present coordinates), an area that included rocks from the Grenville province (see also Dorais and Wintsch, 2001), as well as abundant Ordovician volcanic rocks. The Silurian population, on the other hand, seems to require an eastern source, probably from the Coastal Volcanic Belt. Collectively, the data support the interpretation that the rocks of the Hebron and Berwick formations belong to a single late Silurian depositional regime (for example, Hibbard and others, 2006), and that the Tatnic Hill Formation of the Putnam-Nashoba terrane was closely related to this regime in time but was probably deposited in a separate basin.

\section{Ages of Metamorphism}

Hebron Formation.-Our Hebron Formation data set includes analyses of both newly crystallized metamorphic zircon grains as well as a few overgrowths on magmatic grains (see table 1). Metamorphic zircons are rare in the Berwick and Kittery formations because of their low metamorphic grade, and none were analyzed. However, from the southernmost sample in Connecticut, Carboniferous zircon growth is confirmed by five analyses, and Early Devonian growth is suggested by one analysis. The Carboniferous overgrowths, as well as the metamorphic titanite (table 1; fig. 4C), were probably associated with regional amphibolite facies metamorphism in Connecticut (Wintsch and others, 2003). However, it is possible that the Devonian metamorphic zircon might have formed by contact metamorphism related to emplacement of the Canterbury sill or by regional Acadian metamorphism. The limited data set cannot distinguish between these possible origins.

Tatnic Hill Formation.- In contrast to the data from the Hebron Formation, significant metamorphic zircon crystallized in the Tatnic Hill Formation, where metamorphic intensity reached anatectic conditions (Snyder, 1959). Most zircons in the migmatitic sample T- 1 crystallized at $<408 \mathrm{Ma}$ (that is late Early Devonian, or Emsian), with only a few older cores preserved (fig. 8G, table 1). These detrital cores are small and partially resorbed; apparently, detrital zircons dissolved in the migmatitic melt, and then re-precipitated both as completely new grains and as overgrowths around the remnant cores. Detrital magmatic grains are better preserved in the quartzite sample T-2, (figs. 7C and 7D), probably because its bulk composition was too siliceous for high percentage partial melting. In the quartzite sample, metamorphic overgrowths record Devonian ages similar to and younger than most grains from the migmatitic sample; five additional grains give Carboniferous ages (table 1; fig. 9). The strong concentration of metamorphic ages in the migmatitic Tatnic Hill Formation at $\sim 400 \mathrm{Ma}$ agrees with the ages of monazite recovered from the same sample (fig. $8 \mathrm{H}$ ), and with monazite from migmatite in the Nashoba block in eastern Massachusetts (Hepburn and others, 1995), and the Tatnic Hill Formation around the Willimantic dome (Getty and Gromet, 1992). We thus infer that this $\sim 400 \mathrm{Ma}$ event is regional in the upper pelitic parts of the Putnam-Nashoba terrane in both Connecticut and Massachusetts. Multiple zircon overgrowths in sample T-2 (fig. 7D) with ages through- 
out the middle Paleozoic probably record high-grade crystallization events driven by either deformation or decompression melting that occurred during slow, protracted exhumation of these rocks (Wintsch and others, 1992, 1993). The lack of Devonian monazite and zircon overgrowths in the Hebron Formation is significant because it rules out this high-grade metamorphic event that is so strongly recorded in the structurally underlying Tatnic Hill Formation.

\section{Relationship Between the "Merrimack" and Fredericton Terranes}

Merrimack terrane.-The data and arguments above define the "Merrimack" terrane more narrowly than in previous studies. There is now little doubt that the Hebron and Berwick formations are correlative Late Silurian sedimentary rocks. They share similar Mesoproterozoic and Ordovician-Silurian age populations (see Provenance), and a Ludlovian age of deposition ( $\sim 25-418 \mathrm{Ma})$. Also, they share common lithologies and stratigraphic positions for $>200 \mathrm{~km}$ along strike (see Geologic Setting). Rocks that separate the Hebron Formation in Connecticut from the Berwick Formation along strike in New Hampshire and Maine are the Oakdale and Paxton formations of Massachusetts (Barosh and Moore, 1988; Pease, 1989; Robinson and Goldsmith, 1991). These rocks have been correlated both to the north and south on the basis of similarities in lithology and stratigraphic position (Robinson and Goldsmith, 1991; Bothner and others, 1994, 2004). Our results are consistent with the interpretation that all of these rocks constitute a single depositional regime (see for example, Hibbard and others, 2006), a conclusion that nonetheless should be confirmed with more detrital zircon age data from Massachusetts, and from samples higher and lower in the stratigraphic section. These conclusions also suggest that the Kittery Formation is not part of the Hebron-Berwick sedimentary package. The Kittery Formation lacks the major Ordovician and Silurian populations dominant in all other samples, and it should thus not be assigned to the lithostratigraphic "Merrimack" terrane. The distribution of units shown on figure 1 needs to be redefined.

Merrimack-Fredericton terrane correlation.-Previously, metasedimentary rocks of the Merrimack terrane in eastern New England have been correlated with rocks of the Fredericton trough, New Brunswick and eastern Maine (fig. 1), forming a single Merrimack-Fredericton, or Merrimack-Harpswell belt (for example, Williams and Hatcher, 1983; Rankin, 1994; Robinson and others, 1998; Hussey and others, 1999; Tucker and others, 2001; Hibbard and others, 2006; Rankin and others, 2007). This correlation has been based solely on lithostratigraphic grounds; direct age data confirming that these rocks are time-correlative has been lacking. However, the sediments deposited in the Fredericton trough are Llandoverian (early Silurian; for example, Tucker and others, 2001) and were already folded and weakly metamorphosed by Ludlow time (West and others, 1992, 1995, 2003). Thus the Hebron and Berwick formations are 10 to 20 million years younger than the sedimentary rocks of the Fredericton trough (fig. 10). Deposition of sediments during the Late Silurian time was occurring in the Mascarene basin and the Coastal Volcanic Belt of Maine and Massachusetts (Shride, 1976; Fyffe and others, 1999; Churchill-Dickson, 2004), and in basins now occupied by the Central Maine, Connecticut Valley, and Gaspé terranes (Bradley and others, 2000; Tremblay and Pinet, 2005) but no longer to the east, in the Fredericton belt. Thus, the bulk of the rocks identified as the "Merrimack terrane" in figure 1 are not correlative with the rocks of the Fredericton trough.

The Kittery link.-Because rocks of the Fredericton trough are now known not to correlate with the rocks of the Hebron and Berwick, we consider another possibility: that they correlate with rocks of the Eliot and Kittery formations. Fredericton rocks, mapped as the Flume Ridge and Bucksport, and Appleton Ridge and Digdeguash formations (fig. 10) contain variably calcareous lithic and feldspathic wackes (granofelses) interbedded with partial Bouma sequences of slate (biotite schist) 
probably deposited as turbidites, with mineralogy varying as a function of metamorphic grade (Tucker and others, 2001; Hussey and Marvinney, 2002; Ludman and Berry, 2003). These rocks are quite similar in lithology to the Kittery and Eliot (see Geologic Setting), and are now correlated with them by Bothner and others (2004). Our results do not constrain the age of the Eliot-Kittery to be Early Silurian, but they are consistent with this age assignment as shown in figure 10. The interpretation that these units are older than the Berwick, while structurally overlying it, requires that the Eliot and Kittery formations are allochthonous over the Berwick. This is in fact consistent with the fault contact along the base of the Eliot (Bothner and others, 2004). If valid, then this faulting would have occurred in the Ludlovian, before the intrusion of the Newburyport and Exeter plutons (fig. 10; see below). More data on the ages of detrital zircons in the Eliot and Kittery formations would help resolve this relationship.

\section{TECTONIC SPECULATIONS}

The results presented above concerning provenance of sediments, and ages of deposition, intrusion, and metamorphism constrain plate tectonic scenarios especially for the Silurian of eastern New England. We modify the recent models of Moench and Alienikoff (2003), Tremblay and Pinet (2005), and van Staal (2007) among others to accommodate our results (figure 11). General agreement exists on the involvement of three continental blocks: Laurentia, Gander (Medial New England of Robinson and others, 1998), and Avalon, but the positions, and the polarity of subduction between these blocks, and even existence of oceanic crust between them is not well resolved (for example, Bradley and Tucker, 2002; Tremblay and Pinet, 2005; Gerbi and others, 2006; Schoonmaker and Kidd, 2006). Our tectonic model begins at the end of the Ordovician, and adopts the two opposed subduction zones scenario already proposed in the literature (for example, Bradley and Tucker, 2002; van Staal, 2007, and many others).

\section{Late Ordovician}

In the Late Ordovician, Gander and Laurentia with their opposing arcs were converging as the Iapetus Ocean was closing (for example, Fortey and Cocks, 2003; West and others, 2004; Pollack and others, 2007; Aleinikoff and others, 2007) across two opposing subduction zones (fig. 11). To the west (present coordinates) Early Ordovician Laurentian-derived arcs had become extinct (Karabinos and others, 1998), but the Bronson Hill arc was active, as shown by the ages and isotopic compositions of the Beardsley and Brookfield plutons in western Connecticut (Sevigny and Hanson, 1993, 1995) and plutonic rocks in northern New Hampshire (Tucker and Robinson, 1990; Moench and Aleinikoff, 2003; Aleinikoff and others, 2007; fig. 11). On the eastern side of the Iapetus Ocean, late Ordovician ages and $\mathrm{Pb}$ and $\mathrm{Nd}$ isotopic compositions show that the Victoria arc in Newfoundland (Valverde-Vaquero and others, 2006; Zagorevski and others, 2007) and the Killingworth magmatic arc (Aleinikoff and others, 2007) were actively developing from Gander basement. Tectonic wedging of Gander crust into Laurentian crust (van der Velden and others, 2004; fig. 12) may have begun. To the east, the Gander block was probably undergoing extension in the Exploits back arc basin, and farther east, subduction of an intervening Avalonian oceanic plate was in its early stages (for example, van Staal, 2007).

\section{Late Silurian}

By Late Silurian (Ludlovian) times, most magmatic activity within the Bronson Hill arc had ceased, and sedimentation across a series of broad depositional basins or troughs, including the Central Maine and Merrimack basins (future terranes), separated by horst-like basin highs or 'hinges' (fig. 1) was established (Tremblay and Pinet, 


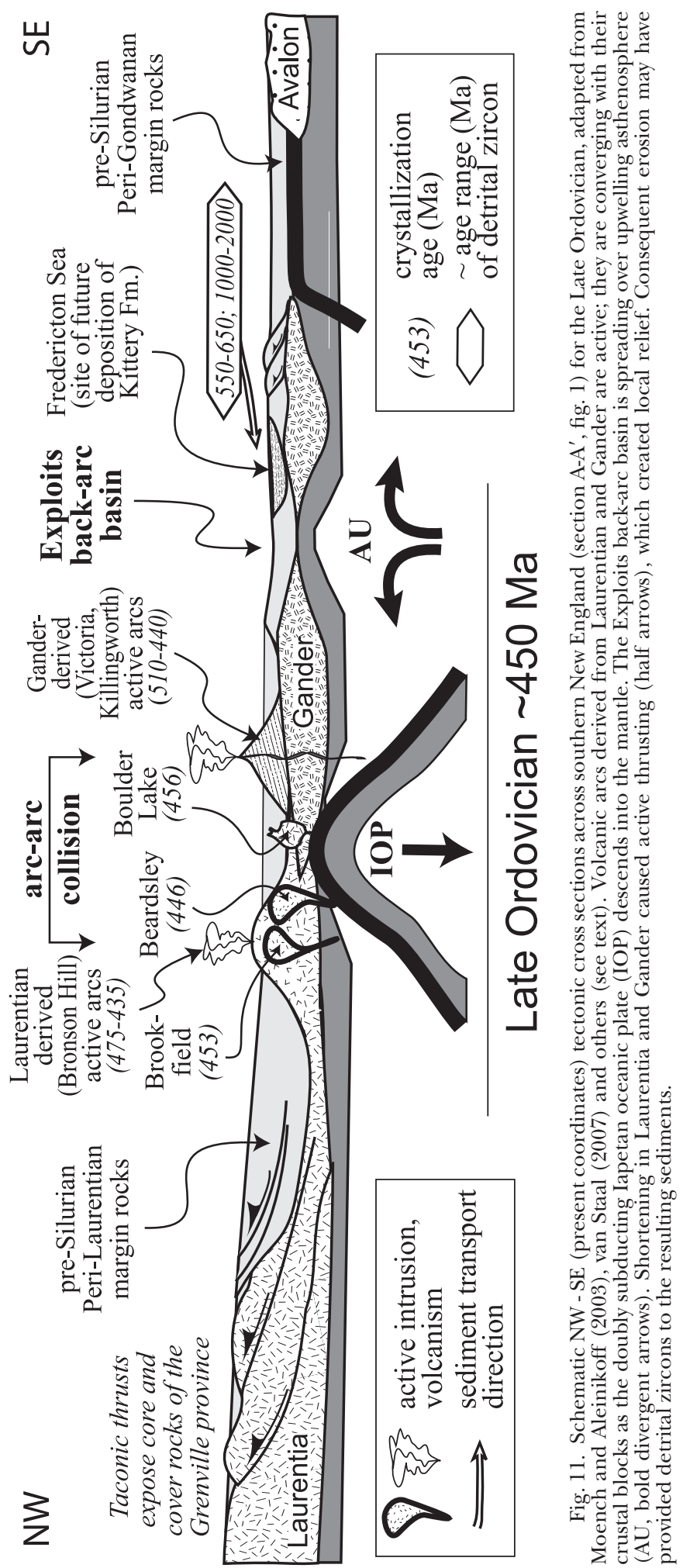


sedimentary rocks in the Merrimack and Putnam-Nashoba terranes, eastern New England 159

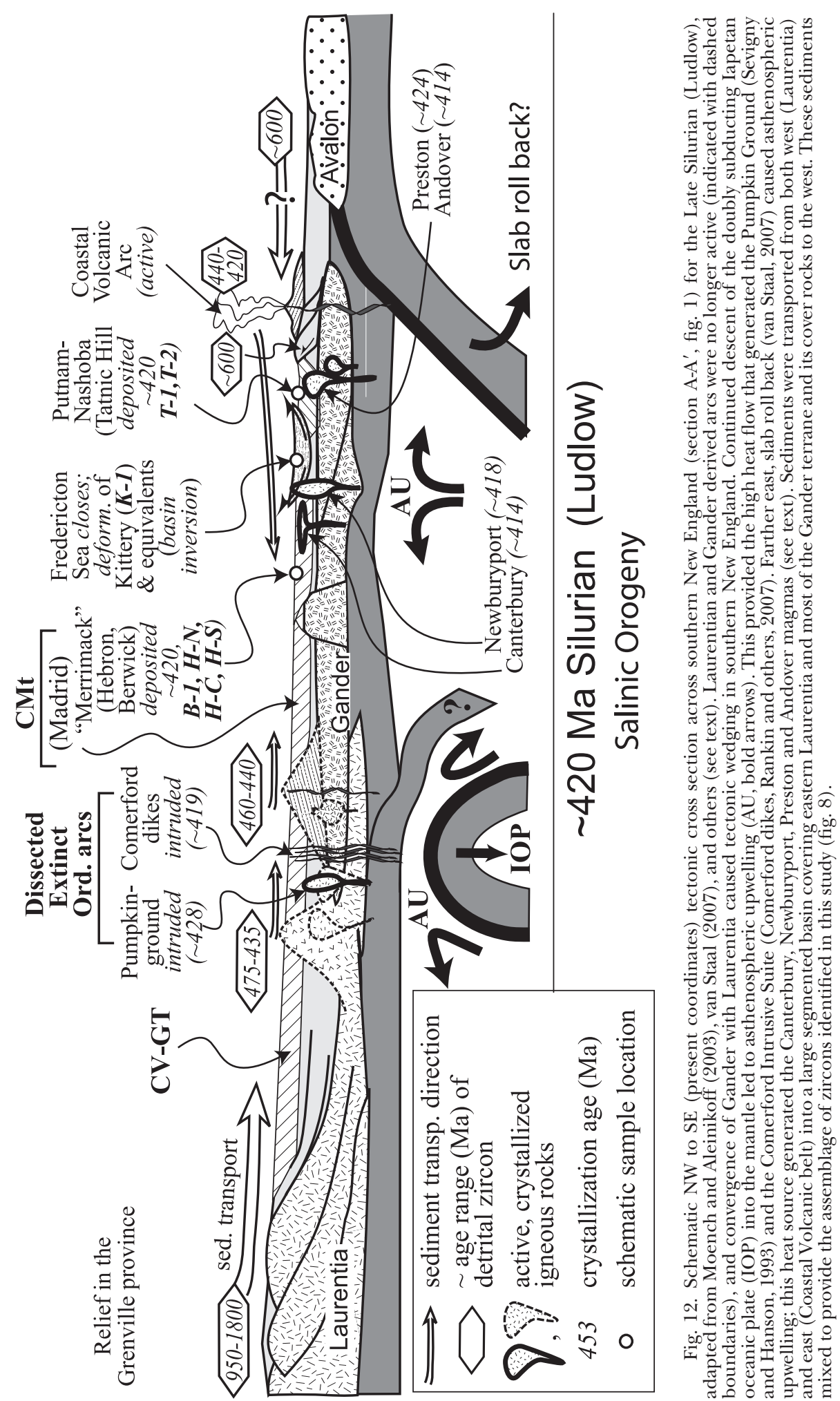


2005; fig. 12). At this time, one of the few Silurian intrusives west of the Bronson Hill arc in southern New England, the Pumpkin Ground Gneiss ( $428 \mathrm{Ma})$, intruded the Beardsley pluton (fig. 12). Its high ${ }^{207} \mathrm{~Pb} /{ }^{204} \mathrm{~Pb}$ composition (Sevigny and Hanson, 1993) suggests that this magma was largely derived from Gander crust. Accordingly, Gander crust is shown in figure 12 to have wedged farther to the west following the Late Ordovician intrusion of the Beardsley Gneiss. This wedging implies continued shortening of the crust between the two arcs, and probably led to the delamination of Laurentian lithospheric mantle. Delamination of Laurentian mantle to the southeast would explain the general southeastern migration of magma across the Central Maine terrane of New Hampshire and Maine as compiled by Lyons and others (1997) and Bradley and others (2000) respectively. Also in the Late Silurian, the Avalon terrane was approaching from the east, producing the active Coastal Volcanic Belt in Maine.

The basins forming between the extinct Ordovician arcs to the west and the Coastal volcanic belt to the east were being filled by a blanket of Silurian turbidites and muds (Bradley and others, 2000; Tremblay and Pinet, 2005), including the Hebron, Berwick and Tatnic Hill formations discussed in this paper (fig. 8). These sediments all contain large populations of Mesoproterozoic and Ordovician detrital zircons. If not recycled, the Mesoproterozoic zircons would have come directly from Grenville crust from the north and west. Erosion of Proterozoic rocks freshly exposed in the Berkshires and Green Mountains during the Taconic or Salinic orogenies (Rodgers, 1970; Robinson and others, 1998; Karabinos and others, 2004) makes these inliers especially attractive sources (see Provenance). An alternative source from the Adirondack highlands is less likely, given that these rocks were probably covered by Cambrian and Ordovician sediments (Rickard, 1969, 1973). A transport path from the north and west would have had to cross Laurentian and Gander margin arcs, by this time largely extinct, but perhaps still exposed as islands, and shedding sediments (hollow arrows, fig. 12). The merger of Gander and Laurentian crusts, as suggested by the Gander provenance of the Pumpkin Ground magma in western Connecticut (Aleinikoff and others, 2007), would have both helped establish relief in the extinct arcs and closed any lingering subduction related trenches that might have acted as sediment traps.

\section{Coastal Volcanic Belt}

The origin of detrital zircons in the Hebron, Berwick, and Tatnic Hill formations with ages $<\sim 440 \mathrm{Ma}$ is not obvious, with few post-Ordovician volcanic rocks documented north and west of our samples. The Llandovery through Pridoli ages of intrusive and volcanic rocks of the Coastal Volcanic Belt in Maine (for example, Bradley and others, 2000; van Wagoner and Dadd, 2003; McLaughlin and others, 2003; Churchill-Dickson, 2004) are correlative with Pridoli Newbury volcanics in Massachusetts (Shride, 1976), Ludlovian Mascarene basin volcanics (for example, Miller and Fyffe, 2002), and Llandovery Kingston arc rocks in New Brunswick (for example, Barr and others, 2002). Westward transport of these volcanics into the Merrimack and Putnam-Nashoba basins would have provided grains with ages of $\sim 440$ to $420 \mathrm{Ma}$ and could explain the full age range of Silurian detrital zircons identified in this study. Thus, transport of sediments from both the west and east into the Ludlovian Hebron and Tatnic Hill basins is implicated.

\section{Putnam-Nashoba Terrane: Tatnic Hill Formation}

In figure 12, the Putnam-Nashoba terrane is shown farthest east, in the back-arc of the Coastal Volcanic arc, a position that accommodates several features of its detrital zircon populations and metamorphic history. First, the very small population of Mesoproterozoic zircons in the Tatnic Hill Formation is explained by the relatively remote position of these rocks relative to exposed Grenville rocks to the west. Second, the relatively large population of late Silurian zircons is accounted for by its close 
proximity to the Late Silurian Coastal Volcanic Belt. Third, the relatively large population of Neoproterozoic grains could be explained by the erosion of exposed Gander basement or by the approaching Avalon terrane from the east. Finally, proximity to the high heat flow regime expected from the Coastal Volcanic arc and slab roll-back (fig. 12, van Staal, 2007) explains the rapid rate of attainment of high grade metamorphism in the Tatnic Hill Formation and the generation of Late Silurian and Early Devonian magmas into the Hebron and the Putnam-Nashoba terrane.

\section{Recycling of Detrital Zircon Grains}

An alternative to these scenarios emerges by the removal of the stipulation that the zircons were deposited as first cycle sediments. There is considerable uncertainty in the path by which the detrital zircons reached the metasediments in this study, and recycling, especially of Mesoproterozoic zircons, is a possibility and even a probability (Becker and others, 2005). The Taconic orogeny to the west of our samples may have exposed Cambrian and Ordovician sediments overlying gneisses of the Grenville province; sediments containing abundant Mesoproterozoic zircons were already well mixed by early Paleozoic sedimentary processes (for example, Gaudette and others, 1981; McLennan and others, 2001; Eriksson and others, 2004). Reworking of these Cambro-Ordovician sediments covering Grenville province inliers in western New England might have provided all of the Mesoproterozoic zircons deposited in the Hebron and Berwick formations without requiring erosion of Mesoproterozoic basement rocks in the Silurian. The origin of Ordovician and Silurian zircons is more likely to have been first cycle because of the short amount of time between their igneous crystallization and Ludlovian time of deposition of the sediments.

The presence in the Kittery Formation of Mesoproterozoic but not Ordovician zircons suggests different sources than those to the west invoked for the Hebron and Berwick formations. Using the arguments above, a western source for the Mesoproterozoic zircons would also have provided Ordovician grains to the Kittery. Because the Kittery lacks Ordovician and Silurian zircons, and because paleocurrent indicators suggest an eastern provenance (Rickerich, 1984), a western source is difficult to defend. The likely Early Silurian depositional age of these rocks further explains their lack of Late Silurian detrital zircons. A source from reworked Ganderian or Avalonian cover sediments satisfies these data. These rocks are known to contain abundant Mesoproterozoic zircons with postulated Baltica and west Amazonia source regions (van Staal and others, 1996; Thompson and Bowring, 2000; Barr and others, 2003; van Staal and others, 2004). With this limited data set currently available in both the Kittery Formation and in Gander cover rocks, an eastern provenance for reworked Mesoproterozoic zircons is possible (Dorais and others, 2005) and is supported by the lack of detrital Ordovician grains.

\section{CONCLUSIONS}

The results of our study contribute to plausible Silurian tectonic scenarios in several ways and thus underscore the value of zircon geochronology in sedimentary and metasedimentary rocks:

(1) The ages of detrital zircons $(\sim 425 \mathrm{Ma})$ and intrusive igneous rocks $(\sim 414$ and $\sim 418 \mathrm{Ma}$ ) in the Hebron Formation of Connecticut and the Berwick Formation of SW Maine constrain their depositional ages to be Late Silurian $(\sim$ Ludlovian). A Late Silurian age for the deposition of the Tatnic Hill Formation is also indicated by its Wenlockian detrital zircons and Emsian metamorphic monazites and zircon overgrowths. Thus, Silurian deposition is extended with confidence from the Central Maine trough south to Long Island Sound (Hebron Formation) and east to the Putnam-Nashoba terrane (Tatnic Hill Formation). 
(2) The dominance of zircons with Mesoproterozoic and Ordovician ages in the Hebron, Berwick, and Tatnic Hill formations suggests a net eastern transport direction for these Silurian sediments. However, the presence of Wenlockian detrital grains is most easily explained by an eastern source in the Coastal Volcanic Belt of Maine and Massachusetts. This interpretation probably requires the closure of subduction zones between Laurentia and Gander that would have acted as traps for sediments from the west.

(3) The Kittery Formation in SW Maine is unique in our study, in that it contains almost exclusively Mesoproterozoic zircons, with only one Ordovician zircon; it also preserves westerly paleocurrent directions. The lack of Ordovician grains suggests a relatively eastern site of erosion, while the lack of Late Silurian grains expected from the Coastal Volcanic Belt in the east is explained by an early Silurian or older age of deposition. We suggest a reassignment of the Kittery and Eliot formations from the Merrimack terrane to the Fredericton terrane. The presence of early Devonian metamorphic zircons and monazites in the Tatnic Hill Formation but not in Merrimack terrane metasedimentary rocks suggests that the former was deposited and rapidly buried in a forearc environment, whereas Merrimack sediments may have been deposited in a back-arc setting.

(4) We suggest that usage of the term "Merrimack" terrane should be limited to Late Silurian sediments and should not include the Eliot and Kittery formations. The bulk of the rocks currently assigned to the "Merrimack" terrane south of Maine do not correlate with the Early Silurian rocks of the Fredericton trough or terrane.

\section{ACKNOWLEDGMENTS}

We thank R. Steinen and J. and B. Stone for help with field work, and logistical support in the field, E. Yacob for help with zircon sample preparation, and J. Wooden, F. Mazdab, and E. Yacob for help with SHRIMP analyses. We are grateful to Spike Berry, Mike Dorais, Alain Tremblay, Doug Rankin, Mary Roden-Tice and Peter Thompson for helpful discussions, and to Bobby Dixon, Dick Goldsmith, Larry Lundgren, Mike Pease, and especially John Rodgers whose undying enthusiasm for southern New England geology inspired RPW to pursue this research. We thank Bill Burton, Martha Growdon, Allan Ludman, Bob Moench, Jeff Pollack, Alain Tremblay, and Dave West for thoughtful reviews of earlier versions of this manuscript. This work was partially supported by NSF grant EAR-0510293 to Wintsch and Dorais, and by funding from the USGS BRASS project to JNA and GJW.

\section{REFERENCES}

Acaster, M., and Bickford, M. E., 1999, Geochronology and geochemistry of Putnam-Nashoba Terrane metavolcanic and plutonic rocks, eastern Massachusetts; constraints on the early Paleozoic evolution of eastern North America: Geological Society of America Bulletin, v. 111, p. 240-253.

Aleinikoff, J. N., Wintsch, R. P., Fanning, C. M., and Dorais, M. J., 2002, U-Pb geochronology of zircon and polygenetic titanite from the Glastonbury Complex, Connecticut, USA; an integrated SEM, EMPA, TIMS, and SHRIMP study: Chemical Geology, v. 188, p. 125-147.

Aleinikoff, J. N., Horton, J. W., Jr., Drake, A. A., Jr, Wintsch, R. P., Fanning, C. M., and Yi, K., 2004, Deciphering multiple Mesoproterozoic and Paleozoic events recorded in zircon and titanite from the Baltimore Gneiss, Maryland; SEM imaging, SHRIMP U-Pb geochronology, and EMP analysis, in Tollo, R. P., Corriveau, L., McLelland, J., and Bartholomew, M. J., editors, Proterozoic tectonic evolution of the Grenville Orogen in North America: Geological Society of America Memoir, v. 197, p. 411-434.

Aleinikoff, J. N., Schenck, W. S., Plank, M. O., Srogi, L., Fanning, C. M., Kamo, S. L., and Bosbyshell, H., 2006, Deciphering igneous and metamorphic events in high grade rocks of the Wilmington Complex, Delaware: Morphology, CL and BSE zoning, and SHRIMP U-Pb geochronology of zircon and monazite: Geological Society of America Bulletin, v. 118, p. 39-64.

Barosh, P. J., and Moore, G. E., Jr., 1988, The Paxton Group of southeastern New England: United States Geological Survey Bulletin, v. 1814, 18 p. 
Barr, S. M., White, C. E., and Miller, B. V., 2002, The Kingston Terrane, southern New Brunswick, Canada; evidence for an Early Silurian volcanic arc: Geological Society of America Bulletin, v. 114, p. 964-982.

Barr, S. M., Davis, D. W., Kamo, S., and White, C. E., 2003, Significance of U-Pb detrital ages in quartzite from peri-Gondwanan terranes, New Brunswick and Nova Scotia, Canada: Precambrian Research, v. 126, p. 123-145.

Becker, T. P., Thomas, W. A., Samson, S. D., and Gehrels, G. E., 2005, Detrital zircon evidence of Laurentian crustal dominance in the Lower Pennsylvanian deposits of the Alleghanian clastic wedge in eastern North America: Sedimentary Geology, v. 182, p. 59-86.

Bellini, F. X., Corkum, D. H., and Stewart, A. J., 1982, Geology of foundation excavations at Seabrook Station, Seabrook, New Hampshire, in Farquhar, O. C., editor, Geotechnology in Massachusetts Conference Proceedings 1980: Amherst, University of Massachusetts, Graduate School, p. 109-117.

Black, L. P., Kamo, S. L., Allen, C. M., Davis, D. W., Aleinikoff, J. N., Valley, J. W., Mundil, R., Campbell, I. H., Korsuch, R. J., Williams, I. S., and Foudoulis, C., 2004, Improved ${ }^{206} \mathrm{~Pb} /{ }^{238} \mathrm{U}$ microprobe geochronology by the monitoring of a trace-element-related matrix effect; SHRIMP, ID-TIMS, ELA-ICP-MS and oxygen isotope documentation for a series of zircon standards: Chemical Geology, v. 205, p. 115-140.

Boger, S. D., Raetz, M., Giles, D., Etchart, E., and Fanning, C. M., 2005, U/Pb age data from the Sunsas region of eastern Bolivia, evidence for the allochthonous origin of the Paragua Block: Precambrian Research, v. 139, p. 121-146.

Bothner, W. A., Boudette, E. L., Fagan, T. J., Gaudette, H. E., Laird, J., and Olszewski, W. J., 1984, Geologic framework of the Massabesic Anticlinorium and the Merrimack Trough, southeastern New Hampshire, in Hanson, L. S., editor, Geology of the Coastal Lowlands; Boston, MA to Kennebunk, ME: Salem, Massachusetts, Department of Geological Sciences, Salem State College, New England Intercollegiate Geological Conference, Guidebook, v. 76, p. 186-206.

Bothner, W.A., Gaudette, H. E., Fargo, T. G., Bowring, S. A., and Isachsen, C. E., 1993, Zircon and sphene U/ $\mathrm{Pb}$ ages of the Exeter Pluton: constraints on the Merrimack Group and part of the Avalon composite terrane: Geological Society of America, Abstracts with Programs, v. 25, p. 485.

Bothner, W. A., Laird, J., Hussey, A. M., II., and West, D. P., Jr., 1994, Status of the Merrimack Group: toward regional consensus: Geological Society of America, Abstracts with Programs, v. 26, p. 8.

Bothner, W. A., Laird, J., Escamilla, C. J., Kerwin, C. W., Schulz, J., and Loveless, J. P., 2004, EDMAPS/ newmaps in southeastern New Hampshire: Geological Society of America, Abstracts with Programs, v. 36, p. 57.

Bradley, D. C., and Tucker, R., 2002, Emsian synorogenic paleogeography of the Maine Appalachians: Journal of Geology, v. 110, p. 483-492.

Bradley, D. C., Tucker, R. D., Lux, D. R., Harris, A. G., and McGregor, D. C., 2000, Migration of the Acadian Orogen and foreland basin across the Northern Appalachians of Maine and adjacent areas: United States Geological Survey, Professional Paper, v. 1624, 55 p.

Bream, B. R., Hatcher, R. D., Jr., Miller, C. F., and Fullagar, P. D., 2004, Detrital zircon ages and Nd isotopic data from the Southern Appalachian crystalline core, Georgia, South Carolina, North Carolina, and Tennessee; new provenance constraints for part of the Laurentian margin: Geological Society of America, Memoir, v. 197, p. 459-475.

Cawood, P. A., McCausland, P. J. A., and Dunning, G. R., 2001, Opening Iapetus; constraints from the Laurentian margin in Newfoundland: Geological Society of America Bulletin, v. 113, p. 443-453.

Cherniak, D. J., and Watson, E. B., 2001, Pb diffusion in zircon: Chemical Geology, v. 172, p. 5-24.

Churchill-Dickson, L. 2004, A late Silurian (Pridolian) age for the Eastport Formation, Maine; a review of the fossil, stratigraphic, and radiometric age data: Atlantic Geology, v. 40, p. 189-195.

Corfu, F., Hanchar, J. M., Hoskin, P. W. O., and Kinny, P., 2003, Atlas of zircon textures, in Hanchar, J. M., and Hoskin, P. W. O., editors., Zircon: Reviews in Mineralogy and Geochemistry, v. 53, p. 469-500.

Dixon, H. R., 1964, The Putnam Group of Eastern Connecticut: U. S. Geological Survey Bulletin, v. 1194-C, p. C1-C12.

Dixon, H. R., and Pessl, F., Jr., 1966, Geologic map of the Hampton Quadrangle, Windham County, Connecticut: U. S. Geological Survey Report, GQ-0468, scale: 1:24,000.

Donohue, C. L., Laird, J., and Bothner, W. A., 1997, Prograde metamorphism in the Berwick Fm. calc-silicates, Merrimack Group, southeastern New Hampshire: Geological Society of America, Abstracts with Programs. v. 29, p. 41-42.

Dorais, M. J., and Wintsch, R. P., 2001, A Laurentian provenance of the Merrimack Belt, New England Appalachians: Geological Society of America, Abstracts with Programs, v. 33, p. 261.

Dorais, M. J., Nelson, W. R., and Tubrett, M. N., 2005, What caused the Acadian Orogeny, New England Appalachians? A provenance study of the Carrabassett Formation, Central Maine Basin: Geological Society of America, Abstracts with Programs, v. 37, n. 1, p. 31.

Elbert, D. C., Harris, A. G., and Denkler, K. E., 1988, Earliest Devonian conodonts from marbles of the Fitch Formation, Bernardston Nappe, north-central Massachusetts: American Journal of Science, v. 288, p. $684-700$

Ericksson, K. A., Campbell, I. H., Palin, J. M., Allen, C. M., and Bock, B., 2004, Evidence for multiple recycling in Neoproterozoic through Pennsylvanian sedimentary rocks of the central Appalachian Basin: Journal of Geology, v. 112, p. 261-276.

Fargo, T. R., and Bothner, W. A., 1995, Polydeformation in the Merrimack Group, southeastern New Hampshire and southwestern Maine: Geological Society of America, Abstracts with Programs, v. 27, p. 42.

Fortey, R. A., Cocks, L., and Robin, M., 2003, Palaeontological evidence bearing on global OrdovicianSilurian continental reconstructions: Earth-Science Reviews, v. 61, p. 245-307. 
Fyffe, L. R., Pickerill, R. K., and Stringer, P., 1999, Stratigraphy, sedimentology and structure of the Oak Bay and Waweig formations, Mascarene Basin: implications for the paleotectonic evolution of southwestern New Brunswick: Atlantic Geology. v. 35, p. 59-84.

Gaudette, H. E., Vitrac-Michard, A., and Allegre, C. J., 1981, North American Precambrian history recorded in a single sample; high-resolution U-Pb systematics of the Potsdam Sandstone detrital zircons, New York State: Earth and Planetary Science Letters, v. 54, p. 248-260.

Gerbi, C. C., Johnson, S. E., Aleinikoff, J. N., Bédard, J. H., Dunning, G. R., and Fanning, C. M., 2006, Early Paleozoic development of the Maine-Quebec Boundary Mountains region: Canadian Journal of Earth Sciences, v. 43, p. $367-389$.

Getty, S. R., and Gromet, L. P., 1992, Geochronological constraints on ductile deformation, crustal extension, and doming about a basement-cover boundary, New England Appalachians: American Journal of Science, v. 292, p. 359-397.

Goldsmith, R., 1991a, Structural and metamorphic history of eastern Massachusetts: United States Geological Survey Professional Paper 1366-H, p. H1-H63.

1991b, Stratigraphy of the Nashoba zone, eastern Massachusetts: an enigmatic terrane: United States Geological Survey Professional Paper 1366-F, p. F1-F22.

Goldstein, A. G., 1989, Tectonic significance of multiple motions on terrane-bounding faults in the Northern Appalachians: Geological Society of America Bulletin, v. 101, p. 927-938.

Gradstein, F. M., Ogg, J. G., and Smith, A. G., 2004, A geologic time scale 2004: Cambridge, Cambridge University Press, $384 \mathrm{p}$.

Hamilton, M. A., McLelland, J., and Selleck, B., 2004, SHRIMP U-Pb zircon geochronology of the anorthosite-mangerite-charnockite-granite suite, Adirondack Mountains, New York; ages of emplacement and metamorphism, in Tollo, R. P., Corriveau, L., McLelland, J., and Bartholomew, M. J., editors, Proterozoic tectonic evolution of the Grenville Orogen in North America: Geological Society of America Memoir, v. 197, p. 337-355.

Heaman, L. M., Gower, C. F., and Perreault, S., 2004, The timing of Proterozoic magmatism in the Pinware Terrane of southeast Labrador, easternmost Quebec and northwest Newfoundland: Canadian Journal of Earth Sciences, v. 41, p. 127-150.

Hepburn, J. C., Dunning, G. R., and Hon, R., 1995, Geochronology and regional tectonic implications of Silurian deformation in the Nashoba Terrane, southeastern New England, U.S.A., in Hibbard, J. P., van Staal, C. R., and Cawood, P. A., editors, Current perspectives in the Appalachian-Caledonian Orogen: Geological Association of Canada, Special Paper 41, p. 349-365.

Hibbard, J. P., van Staal, C. R., Rankin, D. W., and Williams, H., 2006, Lithotectonic map of the Appalachian Orogen, Canada-United States of America: Geological Survey of Canada, "A” Series Map no. 2096A, 2006.

Hogan, J. P., and Sinha, A. K., 1989, Compositional variation of plutonism in the coastal Maine magmatic province; mode of origin and tectonic setting: Augusta, Maine, Maine Geological Survey, Studies in Maine Geology, v. 4, p. 1-33.

Hoskin, P. W. O., and Schaltegger, U., 2003, The composition of zircon and igneous and metamorphic petrogenesis, in Hanchar, J. M., and Hoskin, P. W. O., editors, Zircon: Reviews in Mineralogy and Geochemistry, v. 53, p. 27-62.

Hussey, A. M., II, and Berry, H. N., IV, 2002, Bedrock geology of the Bath 1:100,000 map sheet, coastal Maine: Maine Geological Survey, Bulletin 42, 50 p.

Hussey, A. M., II, and Marvinney, R. G., 2002, Bedrock geology of the Bath 1:100,000 quadrangle, Maine: Maine Geological Survey, Open-File Map 02-152, scale 1:100,000.

Hussey, A. M., II, Rickerich, S. F., and Bothner, W. A., 1984, Sedimentology and multiple deformation of the Kittery Formation, southwestern Maine and southeastern New Hampshire, in Hanson, L. S., editor, Geology of the Coastal Lowlands; Boston, MA to Kennebunk, ME: Salem, Massachusetts, Department of Geological Sciences, Salem State College, New England Intercollegiate Geological Conference, Guidebook, v. 76, p. 47-53.

Hussey, A. M, II, Aleinikoff, J. N., and Marvinney, R. G., 1993, Reinterpretation of age and correlation between tectonostratigraphic units, southwestern Maine: Geological Society of America, Abstracts with Programs, v. 25, p. 25.

Hussey, A. M., II, Ludman, A., Bothner, W. A., and West, D. P., Jr., 1999. Fredericton and Merrimack troughs; once one or always two?: Geological Society of America, Abstracts with Programs, v. 31, p. 25.

Karabinos, P., 2005, Age and style of emplacement of basement uplifts in the northern Appalachians: Geological Society of America, Abstracts with Programs, v. 37, p 20.

Karabinos, P., Samson, S. D., Hepburn, J. C., and Stoll, H. M., 1998, Taconian orogeny in the New England Appalachians: Collision between Laurentia and the Shelburne Falls arc: Geology, v. 26, p. 215-218.

Karabinos, P., Morris, D., and Rayner, N., 2004, Silurian tectonism in the western New England Appalachians: Geological Society of America, Abstracts with Programs, v. 36, n. 2, p. 91.

Ludman, A., and Berry, H. N., IV, 2003, Bedrock geology of the Calais quadrangle, Maine: Maine Geological Survey, Open-file report 03-97, scale: 1:100,000.

Ludwig, K. R., 2001, Squid, version 1.02, A user's manual: Berkeley Geochronology Center Special Publication, n. 2, 21 p.

2003, Isoplot/Ex version 3.00, A geochronological toolkit for Microsoft Excel: Berkeley Geochronology Center Special Publication, n. 4,73 p.

Lyons, J. B., Bothner, W. A., Doolan, B. L., Hatch, N. L., Jr., Moench, R. H., and Stanley, R. S., 1989, Metamorphism and tectonics of eastern and central North America; v. 2, A transect through the New England Appalachians: Washington, D. C., American Geophysical Union, 64 p.

Lyons, J. B., Bothner, W. A., Moench, R. H., and Thompson, J. B., Jr., 1997, Bedrock Geologic Map of New Hampshire: United States Geological Survey Map Series, scales 1:250,000 and 1:500,000. 
McLaughlin, K. J., Barr, S. M., Hill, M. D., Thompson, M. D., Ramezani, J., and Reynolds, P. H., 2003, The Moosehorn Plutonic Suite, southeastern Maine and southwestern New Brunswick: age, petrochemistry, and tectonic setting: Atlantic Geology, v. 39, p. 123-146.

McLennan, S. M., Bock, B., Compston, W., Hemming, S. R., and McDaniel, D. K., 2001, Detrital zircon geochronology of Taconian and Acadian foreland sedimentary rocks in New England: Journal of Sedimentary Research, v. 71, p. 305-317.

McNicoll, V. J., Whalen, J. B., and Stern, R. A., 2003, U-Pb geochronology of Ordovician plutonism, Bathurst mining camp, New Brunswick, in Goodfellow, W. D., McCutcheon, S. R., and Peter, J. M., editors, Massive sulfide deposits of the Bathurst mining camp, New Brunswick, and northern Maine: Economic Geology Monographs, v. 11, p. 203-218.

Miller, B. V., and Fyffe, L. R., 2002, Geochronology of the Letete and Waweig Formations, Mascarene Group, southwestern New Brunswick: Atlantic Geology, v. 38, p. 29-36.

Moecher, D. P., and Wintsch, R. P., 1994, Deformation-induced reconstitution and local resetting of mineral equilibria in polymetamorphic gneisses; tectonic and metamorphic implications: Journal of Metamorphic Geology, v. 12, p. 523-538.

Moench, R., and Aleinikoff, J. N., 2003, Stratigraphy, geochronology, and accretionary terrane settings of two Bronson Hill arc sequences, northern New England: Physics and Chemistry of the Earth, v. 28, p. 113-160.

Nourse, J. A., Premo, W. R., Iriondo, A., and Stahl, E. R., 2005, Contrasting Proterozoic basement complexes near the truncated margin of Laurentia, northwestern Sonora-Arizona international border region, in Anderson, T. H., Nourse, J. A., McKee, J. W., and Steiner, M. B., editors, The Mojave-Sonora Megashear hypothesis; development, assessment, and alternatives: Geological Society of America, Special Paper, v. 393, p. 123-182.

Osberg, P. H., 1968, Stratigraphy, structural geology, and metamorphism of the Waterville - Vassalboro area, Maine: Maine Geological Survey, Bulletin 20,64 p.

Pankiwskyj, K. A., Ludman, A., Griffin, J. R., and Berry, W. B. N., 1976, Stratigraphic relationships on the southeast limb of the Merrimack synclinorium in Central and West-Central Maine, in Lyons, P. C., and Brownlow, A. H., editors, Studies in New England Geology: Geological Society of America Memoir, v. 146 , p. $263-280$.

Pease, M. H., Jr., 1989, Correlation of the Oakdale Formation and Paxton Group of central Massachusetts with strata in northeastern Connecticut: United States Geological Survey Bulletin no. 1796, 26 p., 1 sheet.

Pignolet, S., ms, 1981, Rb-Sr geochronology of the Honey Hill Fault area, eastern Connecticut: Oxford, Ohio, Miami University, Master's thesis, $71 \mathrm{p}$.

Pignolet, S., Grant, N. K., and Hickman, M. H., 1980, Rb-Sr geochronology of the Honey Hill Fault area, eastern Connecticut: Geological Society of America, Abstracts with Programs, v. 12, p. 77-78.

Pollack, J. C., Wilton, D. H. C., van Staal, C. R., and Morrissey, K. D., 2007, U-Pb zircon geochronological constraints on the Late Ordovician-Early Silurian collision of Ganderia and Laurentia along the Dog Bay Line: The terminal Iapetan suture in the Newfoundland Appalachians: American Journal of Science, v. 307 , p. $399-433$.

Rankin, D. W., 1994, Continental margin of the Eastern United States; past and present, in Speed, R. C., editor, Phanerozoic evolution of North American continent-ocean transitions, Boulder, CO: Geological Society of America, DNAG Continent-ocean transect volume, p. 129-218.

Rankin, D. W., Coish, R. A., Tucker, R. D., Peng, Z. X., Wilson, S. A., and Rouff, A. A., 2007, Silurian extension in the upper Connecticut Valley, United States and the origin of middle Paleozoic basins in the Québec Embayment: American Journal of Science, v. 307, p. 216-264

Ratcliffe, N. M., Aleinikoff, J. N., Burton, W. C., and Karabinos, P. A., 1991, Trondhjemitic, 1.35-1.31 Ga gneisses of the Mount Holly Complex of Vermont; evidence for an Elzevirian event in the Grenville basement of the United States Appalachians: Canadian Journal of Earth Sciences, v. 28, p. 77-93.

Ratcliffe, N. M., Walsh, G. J., and Aleinikoff, J., 1997, Basement, metasedimentary and tectonic cover of the Green Mountain massif and western flank of the Chester dome, in Grover, T. W., Mango, H. N., and Hasenohr, E. J., editors, New England Intercollegiate Geological Conference: Castleton, Vermont, Guidebook to Field Trips in Vermont and adjacent New Hampshire and New York, 89th Annual Meeting, p. C6: 1-54.

Rickard, L. V., 1969. Stratigraphy of the Upper Silurian Salina Group, New York, Pennsylvania, Ohio, and Ontario: New York State Museum and Science Service Map and Chart Series 12, 57 p.

1973. Stratigraphy and structure of the subsurface Cambrian and Ordovician carbonates of New York: New York State Museum and Science Service Map and Chart Series 18, 26 p.

Rickerich, S. F., 1984, Sedimentology and stratigraphy of the Kittery Formation near Portsmouth, New Hampshire: Geological Society of America, Abstracts with Programs, v. 16, p. 59.

Rivers, T., 1997, Lithotectonic elements of the Grenville Province: review and tectonic implications: Precambrian Research, v. 86, p. 117-154.

Robinson, P., and Goldsmith, R., 1991, Stratigraphy of the Merrimack Belt, central Massachusetts: United States Geological Survey Professional Paper 1366-E-J, p. G1-G37.

Robinson, P., Tucker, R. D., Bradley, D., Berry, H. N., IV., and Osberg, P. H., 1998, Paleozoic orogens in New England, USA: GFF, v. 120, p. 119-148.

Rodgers, J., 1970, The tectonics of the Appalachians: New York, Wiley-Interscience, 271 p.

1981, The Merrimack synclinorium in northeastern Connecticut: American Journal of Science, v. 281, p. 176-186.

1985, Bedrock geological map of Connecticut: State geological and natural history survey of Connecticut, 2 sheets, scale 1:125,000. 
Schoonmaker, A., and Kidd, W. S. F., 2006, Evidence for a ridge subduction event in the Ordovician rocks of north-central Maine: Geological Society of America Bulletin, v. 118, p. 897-912.

Sevigny, J. H., and Hanson, G. N., 1993, Orogenic evolution of the New England Appalachians of southwestern Connecticut: Geological Society of America Bulletin, v. 105, p. 1591-1605.

_ 1995, Late-Taconian and pre-Acadian history of the New England Appalachians of southwestern: Geological Society of America Bulletin, v. 107, p. 487-498.

Shride, A. F., 1976, Stratigraphy and correlation of the Newbury volcanic complex, northeastern Massachusetts, in Lyons, P. C., and Brownlow, A. H., editors, Contributions to the stratigraphy of New England: Geological Society of America Memoir, v. 148, p. 147-177.

Skehan, J. W., and Rast, N., 1990, Pre-Mesozoic evolution of Avalon terranes of southern New England, in Socci, A. D., Skehan, J. W., and Smith, G. W., editors, Geology of the Composite Avalon Terrane of Southern New England: Geological Society of America Special Paper, v. 245, p. 13-53.

Snyder, G. L., 1959, Bedrock geology of the Norwich Quadrangle, Connecticut: United States Geological Survey Quadrangle Report GQ-144, scale 1:24,000.

1964, Petrochemistry and bedrock geology of the Fitchville Quadrangle, Connecticut: United States Geological Survey, Bulletin 1161-I, 63 p., with map, scale 1:24,000.

Stacey, J. S., and Kramers, J. D., 1975, Approximation of terrestrial Pb isotope composition by a two-stage model: Earth and Planetary Science Letters, v. 26, p. 207-222.

Steiger, R. H., and Jäger, E., 1977, Subcommission on geochronology, convention on the use of decay constants in geo- and cosmochronology: Earth and Planetary Science Letters, v. 36, p. 359-362.

Stewart, D. B., Tucker, R. D., and West, D. P., Jr., 1995, Genesis of Silurian composite terrane in northern Penobscot Bay, in Hussey, A. M., II, and Johnston, R. A., editors, Guidebook to field trips in southern Maine and adjacent New Hampshire: Augusta, Maine, Maine Geological Survey, New England Intercollegiate Geological Conference, Guidebook 87, p. 29-49.

Tassinari, C. C. G., and Macambira, M. J. B., 1999, Geochronological provinces of the Amazonian Craton: Episodes, v. 22, p. 174-182.

Tassinari, C. C. G., Betterncourt, J. S., Geraldes, M. C., Macambira, M. J. B., and Lafon, J. M., 2000, The Amazonian Craton, in Cordani, U. G., Milani, E. J., Thomaz Filho, A., editors, Grafica e Programacao Visual: Rio de Janeiro, Brazil (BRA), p. 41-95.

Thomas, W. A., Becker, T. P., Samson, S. D., and Hamilton, M. A., 2004, Detrital zircon evidence of a recycled orogenic foreland provenance for Alleghanian clastic-wedge sandstones: Journal of Geology, v. 112, p. $23-37$.

Thompson, M. D., and Bowring, S. A., 2000, Age of the Squantum ?Tillite? Boston basin, Massachusetts: U-Pb zircon constraints on terminal Neoproterozic glaciation: American Journal of Science, v. 300, p. $630-$ 655.

Tollo, R. P., Aleinikoff, J. N., Borduas, E. A., Hackley, P., and Fanning, C. M., 2004, Petrologic and geochronologic evolution of the Grenville Orogen, northern Blue Ridge Province, Virginia, in Tollo, R. P., Corriveau, L., McLelland, J., and Bartholomew, M. J., editors, Proterozoic tectonic evolution of the Grenville Orogen in North America: Geological Society of America Memoir, v. 197, p. 411-434.

Tremblay, A., and Pinet, N., 2005, Diachronous supracrustal extension in an intraplate setting and the origin of the Connecticut Valley-Gaspé and Merrimack Troughs, Northern Appalachians: Geological Magazine, v. 142, p. 7-22.

Tucker, R. D., and Gower, C. F., 1994, A U-Pb geochronological framework for the Pinware Terrane, Grenville Province, Southeast Labrador: Journal of Geology, v. 102, p. 67-78.

Tucker, R. D., and Robinson, P., 1990, Age and setting of the Bronson Hill magmatic arc; a re-evaluation based on U-Pb zircon ages in southern New England: Geological Society of America Bulletin, v. 102, p. 1404-1419.

Tucker, R. D., Osberg, P. H., and Berry, H. N., IV, 2001, The geology of a part of the Acadian orogeny across central and eastern Maine: American Journal of Science, v. 301, p. 205-260.

Valverde-Vaquero, P., van Staal, C. R., McNicoll, V., and Dunning, G. R., 2006, Mid-Late Ordovician magmatism and metamorphism along the Gander margin in central Newfoundland: London, Journal of the Geological Society, v. 163, p. 347-362.

van der Velden, A. J., van Staal, C. R., and Cook, F. A., 2004, Crustal structure, fossil subduction, and the tectonic evolution of the Newfoundland Appalachians; evidence from a reprocessed seismic reflection survey: Geological Society of America Bulletin, v. 116, p. 1485-1498.

van Staal, C. R., 2005, The Northern Appalachians, in Selley, R. C., Robin, L., Cocks, M., and Plimer, I. R., editors, Encyclopedia of Geology: Oxford, Elsevier, v. 4, p. 81-91.

2007, Pre-Carboniferous metallogeny of the Canadian Appalachians, in Goodfellow, W. D., editor, Mineral Resources of Canada: A Synthesis of Major Deposit-types, District Metallogeny, the Evolution of Geological Provinces, and Exploration Methods, Jointly by the Mineral Deposit Division of the Geological Association of Canada and the Geological Survey of Canada.

van Staal, C. R., Sullivan, R. W., and Whalen, J. B., 1996, Provenance of tectonic history of the Gander Zone in the Caledonian/Appalachian Orogen; implications for the origin and assembly of Avalon, in Nance, R. D., and Thompson, M. D., editors, Avalonian and Related Peri-Gondwanan Terranes of the Circum-North Atlantic: Geological Society of America Special Paper, v. 304, p. 347-367.

van Staal, C. R., Wilson, R. A., Rogers, N., Fyffe, L. R., Langton, J. P., McCutcheon, S. R., McNicoll, V., and Ravenhurst, C. E., 2003, Geology and tectonic history of the Bathurst Supergroup, Bathurst mining camp, and its relationships to coeval rocks in southwestern New Brunswick and adjacent mine; a synthesis: Economic Geology Monograph, v. 11, p. 37-60.

van Staal, C. R., McNicoll, V., Valverde-Vaquero, P., Barr, S. M., Fyffe, L. R., and Reusch, D. N., 2004, Ganderia, Avalonia, and the Salinic and Acadian orogenies: Geological Society of America, Abstracts with Programs, v. 36, p. 128-129. 
Van Wagoner, N. A., and Dadd, K. A., 2003, A Silurian age for the Passamaquoddy Bay volcanic sequence in southwestern New Brunswick; implications for regional correlations: Geological Society of America, Abstracts with Programs, v. 35, p. 79.

Vermeesch, P., 2004, How many grains are needed for a provenance study?: Earth and Planetary Science Letters, v. 224, p. 441-451.

Walsh, G. J., Aleinikoff, J. N., and Fanning, C. M, 2004, U-Pb geochronology and evolution of Mesoproterozoic basement rocks, western Connecticut, in Tollo, R. P., Corriveau, L., McLelland, J., and Bartholomew, M. J., editors, Proterozoic tectonic evolution of the Grenville Orogen in North America: Geological Society of America Memoir, v. 197, p. 729-753.

Walsh, G. J., Scott, R. B., Aleinikoff, J. N., and Armstrong, T. R., 2006, Preliminary Bedrock geologic map of the Old Lyme quadrangle, New London and Middlesex Counties, Connecticut: U.S. Geological Survey Open File Report 2006-1296, scale 1:24:000.

Walsh, G. J., Aleinikoff, J. N., and Wintsch, R. P., 2007, Origin of the Lyme dome: structural and geochronologic constraints for the times of Alleghanian deformation and decompression melting: American Journal of Science, v. 307, p. 168-215.

West, D. P., Jr., Ludman, A., and Lux, D. R., 1992, Silurian age for the Pocomoonshine Gabbro-Diorite, southeastern Maine and its regional tectonic implications: American Journal of Science, v. 292, p. 253-273.

West, D. P., Jr., Guidotti, C. V., and Lux, D. R., 1995, Silurian orogenesis in the western Penobscot Bay region, Maine: Canadian Journal of Earth Sciences, v. 32, p. 1845-1858.

West, D. P., Jr., Beal, H. M., and Grover, T. W., 2003, Silurian deformation and metamorphism of Ordovician arc rocks of the Casco Bay Group, south-central Maine: Canadian Journal of Earth Sciences, v. 40, p. 887-905.

West, D. P., Jr., Coish, R. A., and Tomascak, P. B., 2004, Tectonic setting and regional correlation of Ordovician metavolcanic rocks of the Casco Bay Group, Maine; evidence from the trace element and isotope geochemistry: Geological Magazine, v. 141, p. 125-140.

Williams, H., and Hatcher, R. D., Jr., 1983, Appalachian suspect terranes, in Hatcher, R. D., Jr., Williams, H. and Zietx, I., editors, Contributions to the tectonics and geophysics of mountain chains: Geological Society of America Memoir, v. 158, p. 33-53.

Williams, I. S., 1998, U-Th-Pb geochronology by ion microprobe, in McKibben, M. A., Shanks, W. C., III, and Ridley, W. I., editors, Applications of microanalytical techniques to understanding mineralizing processes: Reviews of Economic Geology, v. 7, chapter 1, p. 1-35.

Williams, I. S., and Hergt, J. M., 2000, U-Pb dating of Tasmanian dolerites: A cautionary tale of SHRIMP analysis of high-U zircon, in Woodhead, J. D., and others, editors, Beyond 2000: New frontiers in isotope research, Lorne, Australia, abstracts and proceedings: Melbourne, Australia, University of Melbourne, p. 185-188.

Wintsch, R. P., Sutter, J. F., Kunk, M. J., Aleinikoff, J. N., and Dorais, M. J., 1992, Contrasting P-T-t paths; thermochronologic evidence for a late Paleozoic final assembly of the Avalon composite terrane in the New England Appalachians: Tectonics, v. 11, p. 672-689.

Wintsch, R. P., Sutter, J. F., Kunk, M. J., Aleinikoff, J. N., and Boyd, J. L., 1993, Alleghanian assembly of Proterozoic and Paleozoic lithotectonic terranes in south central New England: New constraints from geochronology and petrology, in Cheney, J. T., and Hepburn, T. C., editors, Field Trip Guidebook for the Northeastern United States, 1993, Boston GSA: University of Massachusetts, Geology Department, Contribution No. 67, v. 1, p. H1-H30.

Wintsch, R. P., Kelsheimer, K. L., Kunk, M. J., and Aleinikoff, J. N., 2001, A new look at the Alleghanian overprint of Acadian metamorphic rocks in southern New England: Evidence from structure, petrology and thermochronology, in West, D. P., and Bailey, R. H., editors, Guidebook for geological field trips in New England: Boston, Geological Society of America Annual Meeting, p. V1-V26.

Wintsch, R. P., Kunk, M. J., Boyd, J. L., and Aleinikoff, J. N., 2003, P-T-t paths and differential Alleghanian loading and uplift of the Bronson Hill terrane, south-central New England: American Journal of Science, v. 303, p. 410-446.

Wintsch, R. P., Aleinikoff, J. N., Webster, J. R., and Unruh, D. M., 2005, The Killingworth Complex: A middle and late Paleozoic magmatic and structural dome, in McHone, N. W., and Peterson, M. J., editors, Guidebook for Field Trips in Connecticut: State Geological and Natural History Survey of Connecticut, Guidebook No. 8, p. 305-324.

Zagorevski, A., Rogers, N., van Staal, C. R., McNicoll, V., Lissenberg, C. J., and Valverde-Vaquero, P., 2006, Lower to Middle Ordovician evolution of peri-Laurentian arc and backarc complexes in Iapetus; constraints from the Annieopsquotch accretionary tract, central Newfoundland: Geological Society of America Bulletin, v. 118, p. 324-342.

Zagorevski, A., van Staal, C. R., McNicoll, V., and Rogers, N., 2007, Upper Cambrian to upper Ordovician island arc activity in the Victoria Lake supergroup, central Newfoundland: tectonic development of the northern Ganderian Margin: American Journal of Science, v. 307, p. 339-370.

Zartman, R. E., and Marvin, R. F., 1991, Radiometric ages of rocks in Massachusetts, in Hatch, N. L., Jr. editor, The bedrock geology of Massachusetts: United States Geological Survey Professional Paper 1366J, p. J1-J19.

Zartman, R. E., and Naylor, R. S., 1984, Structural implications of some radiometric ages of igneous rocks in southeastern New England: Geological Society of America Bulletin, v. 95, p. 522-539.

Zen, E., Goldsmith, R., Ratcliffe, N. M., Robinson, P., and Stanley, R. S., compilers, 1983, Bedrock geologic map of Massachusetts: United States Geological Survey, Special Geologic Map, 3 sheets, Scale 1:250,000. 